Biogeosciences Discuss., doi:10.5194/bg-2017-127, 2017

Manuscript under review for journal Biogeosciences

Discussion started: 3 May 2017

(C) Author(s) 2017. CC-BY 3.0 License.

\title{
1 Vulnerability of soil organic matter of anthropogenically disturbed 2 organic soils
}

3 Annelie Säurich ${ }^{1}$, Bärbel Tiemeyer ${ }^{1}$, Axel Don ${ }^{1}$, Michel Bechtold ${ }^{1,2}$, Wulf Amelung ${ }^{3}$, Annette 4 Freibauer $^{1,4}$

6 Thünen Institute of Climate-Smart Agriculture, Bundesallee 50, 38116 Braunschweig, Germany

$7{ }^{2}$ now at: KU Leuven, Department of Earth and Environmental Sciences, Division Soil and Water Management, 8 Celestijnenlaan 200 E, B-3001 Heverlee, Belgium

$9{ }^{3}$ University of Bonn, Institute of Crop Science and Resource Conservation, Soil Science and Soil Ecology, Nussallee 13, 1053115 Bonn, Germany

$11{ }^{4}$ now at: Bavarian State Research Center for Agriculture, Institute of Organic Farming, Agricultural Sciences and Natural 12 Resources, Lange Point 12, 85354 Freising, Germany

14 Correspondence to: Bärbel Tiemeyer (baerbel.tiemeyer@thuenen.de) 
Biogeosciences Discuss., doi:10.5194/bg-2017-127, 2017

Manuscript under review for journal Biogeosciences

Discussion started: 3 May 2017

(c) Author(s) 2017. CC-BY 3.0 License.

\section{Abstract}

17 Drained peatlands are hotspots of carbon dioxide $\left(\mathrm{CO}_{2}\right)$ emissions from agriculture. As a consequence of both drainageinduced mineralisation and anthropogenic mixing with mineral soils, large areas of former peatlands under agricultural use now contain soil organic carbon (SOC) at the boundary between mineral and organic soils and/or underwent a secondary transformation of the peat (e.g. formation of aggregates). However, low carbon organic soils have rarely been studied since previous research has mainly focused on either mineral soils or true peat soils. The aim of the present study was to evaluate the soil organic matter (SOM) vulnerability of the whole range of organic soils including very carbon rich mineral soils (73 $\mathrm{g}$ $\mathrm{kg}^{-1}<\mathrm{SOC}<569 \mathrm{~g} \mathrm{~kg}^{-1}$ ) and to identify indicators for mineralisation of such anthropogenically disturbed organic soils. Using a large sample pool from the German Agricultural Soil Inventory, 91 soil samples were selected covering a broad range of soil and site characteristics. Fen and bog samples were grouped into disturbance classes according to their pedogenetic features. Potential $\mathrm{CO}_{2}$ production by aerobic incubation was then measured. Specific basal respiration rates (SBR) per unit SOC showed the highest potential emissions for heavily disturbed fen $\left(12.1 \pm 5.0 \mu \mathrm{g} \mathrm{CO}_{2}-\mathrm{C} \mathrm{g} \mathrm{SOC}^{-1} \mathrm{~h}^{-1}\right)$ and moderately disturbed bog samples $\left(10.3 \pm 5.2 \mu \mathrm{g} \mathrm{CO}_{2}-\mathrm{C} \mathrm{g} \mathrm{SOC}^{-1} \mathrm{~h}^{-1}\right)$. Surprisingly, SOM vulnerability increased with an increasing degree of disturbance and a decreasing SOC content, indicating positive feedback mechanisms as soon as peat soils are disturbed by drainage. Furthermore, with increasing degree of disturbance the variability of the SBR increased drastically, but correlations between soil properties and SBR could not be identified. Respiration rates increased more strongly with an increasing degree of disturbance in bog than in fen samples. Peat properties that positively influenced the turnover of SOM in less disturbed soil samples were mainly $\mathrm{pH}$ value and nitrogen content, while phosphorus was important for the mineralisation of increasingly disturbed samples and bog peat in general. Furthermore, a narrow carbon-to-nitrogen ratio correlated strongly with potential emissions. Given the high potential of $\mathrm{CO}_{2}$ emissions from organic soils with a low SOC content, mixing with mineral soil does not seem to be a promising option for decreasing emissions. 
Biogeosciences Discuss., doi:10.5194/bg-2017-127, 2017

Manuscript under review for journal Biogeosciences

Discussion started: 3 May 2017

(c) Author(s) 2017. CC-BY 3.0 License.

\section{$1 \quad$ Introduction}

38 Organic soils worldwide cover approximately 330 million ha or $2.2 \%$ of the global terrestrial surface. One third of this area 39 is in Europe (Tubiello et al., 2016), corresponding to $3 \%$ of the European landmass (Montanarella et al., 2006). Despite the small extent of this area, peatlands store more than one third of global soil organic carbon (SOC) (Gorham, 1991). Moreover, intact peatlands under waterlogged conditions are ongoing carbon (C) sinks in that their mineralisation rates are lower than their biomass production rates (Clymo et al., 1998). Large areas of peatland are drained for agriculture, forestry and peat mining for energy and horticulture. To date 25.5 million ha of peatlands worldwide have been drained for agriculture alone, of which around $60 \%$ are in the boreal or temperate zone (Tubiello et al., 2016). The majority of the drained peatlands in Russia, Belarus, Ukraine, Poland, the Netherlands and Germany are used for agricultural purposes, primarily as grassland (Joosten and Clarke, 2002). These anthropogenic impacts lead to a disturbance of the peatlands' hydrological and biogeochemical cycles, e.g. to the destabilisation of the soil organic matter (SOM) (Holden et al., 2004). Thus drainage turns peatlands into net greenhouse gas (GHG) sources, which emit large amounts of carbon dioxide $\left(\mathrm{CO}_{2}\right)$ and nitrous oxide $\left(\mathrm{N}_{2} \mathrm{O}\right)$ (Maljanen et al., 2010; Tiemeyer et al., 2016).

Furthermore, drainage alters physical and chemical peat properties considerably. The loss of buoyancy following drainage leads to compaction and thus to an increase in bulk density and decrease in total porosity (Rovdan et al., 2002). Compaction and mineralisation jointly cause subsidence of the soil surface. Mineralisation and transformation of SOM lead to the formation of aggregates, shrinkage cracks, earthification and finally to the formation of a dusty, fine-grained ("moorshy") horizon (e.g. Ilnicki and Zeitz, 2003). Consequently, the majority of topsoils of drained agricultural peatlands show a von Post decomposition degree of H10 (von Post, 1924).

Drainage favours carbon over nitrogen $(\mathrm{N})$ mineralisation and microbial $\mathrm{N}$ immobilisation during decomposition. Thus, the concentrations of $\mathrm{N}$ increase, and both the $\mathrm{C}$ concentration and $\mathrm{C}: \mathrm{N}$-ratio decrease with increasing degrees of SOM decomposition, especially in the topsoil (Wells and Williams, 1996). Phosphorus (P) concentrations usually increase after drainage, while potassium (K), calcium ( $\mathrm{Ca}$ ) and iron (Fe) concentrations decrease (Sundström et al., 2000; Wells and Williams, 1996; Zak et al., 2010). As aerobic decomposers preferably use the lighter ${ }^{12} \mathrm{C}$ for respiration, the remaining peat is enriched in ${ }^{13} \mathrm{C}$ (Ågren et al., 1996). Similarly, drained peatlands are depleted in ${ }^{14} \mathrm{~N}$ and show increases in $\delta^{15} \mathrm{~N}$ values (Krüger et al., 2015).

Besides drainage, the conversion from pristine peatlands to agricultural land can comprise the active enrichment of the mineral soil fraction in the top peat layer in order to enhance trafficability. This can be achieved by mixing with mineral soil layers underlying the peat (deep ploughing) or by surface application of mineral soil with or without subsequent ploughing 66 (Göttlich, 1990; Okruszko, 1996). As a consequence of both drainage-induced mineralisation and anthropogenic mineral soil mixing, especially the topsoils of large areas of former peatlands under agricultural use contain SOC at concentrations between those of mineral and organic soils (Schulz and Waldeck, 2015). 
Biogeosciences Discuss., doi:10.5194/bg-2017-127, 2017

Manuscript under review for journal Biogeosciences

Discussion started: 3 May 2017

(c) Author(s) 2017. CC-BY 3.0 License.

69 As previous investigations mainly have focused either on mineral $\left(<150 \mathrm{~g} \mathrm{SOM} \mathrm{kg}^{-1}\right.$ according to the German definition, 70 Ad-Hoc-AG Boden, 2005) or "true" peat soils (> $\left.300 \mathrm{~g} \mathrm{SOM} \mathrm{kg}^{-1}\right)$, there are very few studies on soil properties or SOM 71 dynamics of "low C organic soils" (between 150 and $300 \mathrm{~g} \mathrm{SOM} \mathrm{kg}^{-1}$ ). However, measurements of GHG emissions in the 72 field have shown that organic soils with a SOC content of around $100 \mathrm{~g} \mathrm{~kg}^{-1}$ still emit large amounts of $\mathrm{CO}_{2}$ similar to the 73 levels emitted by "true" peat soils (Leiber-Sauheitl et al., 2014; Tiemeyer et al., 2016). This is rather surprising as the 74 remaining organic matter should not be readily available for mineralisation, given that the SOC content at this stage of 75 decomposition is fairly low and $\mathrm{CO}_{2}$ emissions and SOC content are closely related in mineral soils (Don et al., 2013; Wang

76 et al., 2003). However, only a few field studies have been carried out and there is therefore very limited knowledge about the 77 separate effects of climate, hydrology and soil properties. The reasons behind the relatively high $\mathrm{CO}_{2}$ emissions of the whole 78 continuum of organic soils, including those bordering mineral ones, are not yet clear. Peat properties and SOM quality 79 obviously influence the $\mathrm{CO}_{2}$ emissions of disturbed peatlands (Brouns et al., 2016; Laiho, 2006), but there is a lack of any 80 systematic evaluation of the vulnerability of a wide range of organic soils, including strongly disturbed ones.

81 The aims of this study, were i) to assess the sensitivity of SOM from anthropogenically disturbed organic soils under 82 agricultural use to mineralisation under aerobic conditions and ii) to determine the indicators and drivers of the vulnerability 83 of SOM. In this context, disturbance was defined as the effect of soil-forming processes induced by drainage and/or by the 84 mixing of peat with mineral soil. For this purpose, 91 samples of soils were examined under cropland and grassland from 85 across Germany, ranging from carbon-rich mineral soil (70 g SOC kg-1) to "true" peatlands (up to $\left.560 \mathrm{~g} \mathrm{SOC} \mathrm{kg}^{-1}\right)$. As a 86 simulation of the potential effects of drainage, all the samples were aerobically incubated in the laboratory at standardised 87 water content. 
Biogeosciences Discuss., doi:10.5194/bg-2017-127, 2017

Manuscript under review for journal Biogeosciences

Discussion started: 3 May 2017

(c) Author(s) 2017. CC-BY 3.0 License.

\subsection{Sample selection}

91 The samples used in this study came from the German Agricultural Soil Inventory, the aim of which is to improve understanding of SOC stocks in agricultural soils. During the soil inventory, agricultural soils in Germany were sampled following standardised protocols in an $8 \times 8 \mathrm{~km}$ grid (> 3,000 sites) at seven depth increments per soil pit (10, 30, 50, 70, 100, 150 and $200 \mathrm{~cm}$ ). All the samples were analysed for SOC and bulk density, as well as for basic explanatory soil properties (Table 1, see section 2.2). 91 samples of organic soil horizons from 67 sites were selected. The basic criteria were a SOC content $>70 \mathrm{~g} \mathrm{~kg}^{-1}$ and a sampling depth $>10 \mathrm{~cm}$ to reduce the influence of potential root biomass residues in the samples. Roots have generally been separated by hand, but this might be challenging in organic soils. The final sample selection was based on a cluster analysis to optimally cover the total parameter range, as well as land use, peat type (bog/fen) and geographical position. The selected samples included croplands (19\%) and grasslands (81 \%), which correspond to the dominant agricultural land use of organic soils in Germany. In addition to the 91 samples, ten samples of three anthropogenically undisturbed peatlands (bog, transition bog and fen) were sampled.

Table 1: Soil properties of the selected soil samples as medians and standard errors. Standard parameters measured in the German Agricultural Soil Inventory: SOC: soil organic carbon content, $\mathrm{N}_{\mathrm{t}}$ : total nitrogen content, $\mathrm{CaCO}_{3}$ : calcium carbonate content, C:N-ratio: carbon to nitrogen ratio, $\rho$ : bulk density, $\mathrm{pH}$-value, texture $\left(*\right.$ only determined for samples with SOC $\left.<172 \mathrm{~g} \mathrm{~kg}^{-1}\right)$. Additional parameters

\begin{tabular}{|c|c|c|c|}
\hline Parameter & Median & Min. & Max. \\
\hline SOC $\left(\mathrm{g} \mathrm{kg}^{-1}\right)$ & $257.0 \pm 15.5$ & 73.4 & 568.9 \\
\hline $\mathrm{N}_{\mathrm{t}}\left(\mathrm{g} \mathrm{kg}^{-1}\right)$ & $11.7 \pm 0.8$ & 2.9 & 36.5 \\
\hline $\mathrm{CaCO}_{3}\left(\mathrm{~g} \mathrm{~kg}^{-1}\right)$ & $0.0 \pm 1.2$ & 0.0 & 580.0 \\
\hline $\mathrm{C}: \mathrm{N}$-ratio & $18.0 \pm 1.2$ & 9.9 & 72.6 \\
\hline$\rho\left(\mathrm{g} \mathrm{cm}^{-3}\right)$ & $0.30 \pm 0.03$ & 0.07 & 0.99 \\
\hline $\mathrm{pH} \mathrm{CaCl}{ }_{2}$ & $4.9 \pm 0.1$ & 2.5 & 7.4 \\
\hline Sand content $(\%)^{*}$ & $44.7 \pm 4.9$ & 2.5 & 87.9 \\
\hline Silt content $(\%)^{*}$ & $25.8 \pm 2.5$ & 6.4 & 62.1 \\
\hline Clay content $(\%)^{*}$ & $20.9 \pm 3.1$ & 3.9 & 62.8 \\
\hline $\mathrm{Fe}_{\mathrm{O}}\left(\mathrm{g} \mathrm{kg}^{-1}\right)$ & $11.8 \pm 1.7$ & 0.4 & 108.3 \\
\hline $\mathrm{P}_{\mathrm{CAL}}\left(\mathrm{mg} \mathrm{kg}^{-1}\right)$ & $12.4 \pm 5.9$ & 0.4 & 365.6 \\
\hline$\delta^{13} \mathrm{C}(\%)$ & $-28.14 \pm 0.10$ & -30.42 & -25.47 \\
\hline$\delta^{15} \mathrm{~N}(\% 0)$ & $2.05 \pm 0.24$ & -2.55 & 11.23 \\
\hline
\end{tabular}


Biogeosciences Discuss., doi:10.5194/bg-2017-127, 2017

Manuscript under review for journal Biogeosciences

Discussion started: 3 May 2017

(c) Author(s) 2017. CC-BY 3.0 License.

\subsection{Soil properties}

108 Concentrations of total $\mathrm{C}$ and $\mathrm{N}\left(\mathrm{N}_{\mathrm{t}}\right)$, as well as the total inorganic carbon content for samples with carbonate $\left(\mathrm{pH}_{\mathrm{CaCl} 2}>6.2\right)$, were measured by dry combustion (RC 612, LECO Corporation, St. Joseph, USA). Stable isotope analysis $\left(\delta^{13} \mathrm{C}\right.$ and $\left.\delta^{15} \mathrm{~N}\right)$ was performed using a mass spectrometer coupled with an elemental analyser (Isoprime 100 and Vario Isotope, Elementar, Hanau, Germany) via a continuous flow system. Samples containing carbonates underwent a carbonate destruction (volatilisation method) on the basis of Hedges and Stern (1984) and Harris et al. (2001) prior to isotope analysis. The isotope ratios are expressed in per mill, $\delta^{13} \mathrm{C}$ relative to VPDB standard and $\delta^{15} \mathrm{~N}$ relative to atmospheric nitrogen standard.

Poorly crystalline and organically-bound iron oxides $\left(\mathrm{Fe}_{\mathrm{O}}\right)$ were extracted with an acidic ammonium oxalate solution. The extraction took place in the dark to avoid photo-reduction of ferrous iron oxides (Schwertmann, 1964). The concentration of extracted $\mathrm{Fe}_{\mathrm{O}}$ was measured by atomic absorption spectrometry (AA-280FS, Varian, Palo Alto, USA).

Plant-available concentrations of phosphorus were determined by calcium acetate lactate (CAL) extraction (Schüller, 1969). $\mathrm{P}_{\mathrm{CAL}}$ concentrations were measured using the molybdenum blue method (Murphy and Riley 1962). 4-12, UGT, Müncheberg, Germany) after aggregate destruction and the removal of salt and SOM using $\mathrm{H}_{2} \mathrm{O}_{2}$ (Vos et al., 2016). Undisturbed soil samples in rings were dried at $105^{\circ} \mathrm{C}$ until constant mass and subsequently weighed to determine bulk density $(\rho)$. The $\mathrm{pH}$ values were measured using $0.01 \mathrm{~mol} / \mathrm{L} \mathrm{CaCl}_{2}$ and a glass electrode. Electrical conductivity (EC) was determined in a water solution.

\subsection{Incubation experiments: Basal respiration and substrate-induced respiration}

The soil samples were incubated aerobically under optimum moisture and constant temperature $\left(23{ }^{\circ} \mathrm{C}\right)$ conditions to determine basal soil respiration (BR) and substrate-induced respiration (SIR), which was used to calculate microbial biomass (Anderson and Domsch, 1978).

The dried $\left(40^{\circ} \mathrm{C}\right)$ and $2 \mathrm{~mm}$ sieved soil samples were moistened to a standardised water content of $60 \%$ water-filled pore space. The apparent porosity of the dried and sieved sample was determined from the bulk density of the loose sample. The necessary amount of water to reach $60 \%$ water-filled pore space was then applied to the soil samples under continuous stirring to ensure uniform rewetting. Afterwards, the moistened samples were stored in darkness under aerobic conditions for 7 days at $6{ }^{\circ} \mathrm{C}$ and then for a further 7 days at $23^{\circ} \mathrm{C}$ for pre-incubation. On day 14, the soil samples were prepared for incubation in a semi-automatic incubation device using its flow-through mode (Heinemeyer et al., 1989). Three replicates (20 g dry wt.) of each sample were put loosely in acrylic glass tubes $(4 \mathrm{~cm}$ diameter) and enclosed at both ends with polystyrene foam stoppers. Humidified ambient air flowed through 24 independent lines containing the soil samples at flow rates between 160 and $180 \mathrm{ml} \mathrm{min}^{-1}$. An infrared $\mathrm{CO}_{2}$ gas analyser (ADC-255-MK3, Analytical Development Co. Ltd., 
Biogeosciences Discuss., doi:10.5194/bg-2017-127, 2017

Manuscript under review for journal Biogeosciences

Discussion started: 3 May 2017

(c) Author(s) 2017. CC-BY 3.0 License.

Hoddesdon, UK) was used to measure $\mathrm{CO}_{2}$ concentrations. Each replicate sample was measured hourly over an incubation time of at least $40 \mathrm{~h}$ or until a relatively constant BR was reached (up to $90 \mathrm{~h}$ ).

Afterwards soil samples were amended with a mixture of $100 \mathrm{mg}$ glucose and $100 \mathrm{mg}$ talcum using an electronic stir for $30 \mathrm{~s}$ to determine the active microbial biomass using the SIR method. The mixture was then incubated again for $6 \mathrm{~h}$ to obtain the maximal initial respiratory response of the microbial biomass (Anderson et al., 1995).

\subsection{Data analysis}

Statistical analysis was performed using the R software environment (version R-3.1.3, R Core Team, 2015).

\subsubsection{Determination of basal soil respiration}

The measured BR is expressed as $\mu \mathrm{g} \mathrm{CO}_{2}-\mathrm{C}$ g soil ${ }^{-1} \mathrm{~h}^{-1}$ and the specific basal respiration (SBR) is normalised by the sample's SOC content into $\mu \mathrm{g} \mathrm{CO}_{2}-\mathrm{Cg} \mathrm{SOC}^{-1} \mathrm{~h}^{-1}$. An exponential model was fitted simultaneously to all three incubation replicates to determine the equilibrium values of the SBR (Figure):

$\mathrm{CO}_{2}-\mathrm{C}(\mathrm{t})=\mathrm{a}-(\mathrm{a}-\mathrm{SBR})\left(1-\mathrm{e}^{-\mathrm{k} * \mathrm{t}}\right)$

where $\mathrm{CO}_{2}-\mathrm{C}(\mathrm{t})\left[\mu \mathrm{g} \mathrm{CO}_{2}-\mathrm{C} \mathrm{g} \mathrm{SOC}{ }^{-1} \mathrm{~h}^{-1}\right]$ is the specific $\mathrm{CO}_{2}$ production per hour, $a$ [ $\left.\mu \mathrm{g} \mathrm{CO}_{2}-\mathrm{C} \mathrm{g} \mathrm{SOC} \mathrm{SO}^{-1}\right]$ is the initial respiration and $k\left[\mathrm{~h}^{-1}\right]$ is the change rate of SBR.

To achieve an objective quantification of the (specific) basal respiration and its uncertainty, the R package "dream" was used (Guillaume and Andrews, 2012), which is based on the iterative Markov Chain Monte Carlo (MCMC) approach. This method is basically a Markov chain that generates a random walk through the high-probability-density region in the parameter space, separating behavioural from non-behavioural solutions following the probability distribution (Vrugt et al., 2009b). The differential evolution adaptive metropolis (DREAM) algorithm is an efficient MCMC sampler that runs multiple Markov chains simultaneously for global exploration of the parameter space. In doing so, DREAM uses a differential algorithm for population evolution and a metropolis selection rule to decide whether a population of candidate points is accepted or not. After the burn-in period, the convergence of individual chains is checked using the Gelman and Rubin (1992) convergence criterion, which examines the variance between and within chains (Vrugt et al., 2008, 2009a).

Once the convergence criterion of Gelman and Rubin was $<1.01$, another 500,000 simulations were run to determine the posterior probability density functions of the model parameters, which were used to calculate the median and the 2.5 and $97.5 \%$ quantiles.

For the evaluation of the SIR experiment, the value of the maximum initial respiratory response was identified manually and then transcribed to microbial biomass (SIR- $\mathrm{C}_{\text {mic }}$ ) $\left[\mu \mathrm{g} \mathrm{g}^{-1}\right.$ soil] as follows (Kaiser et al., 1992):

SIR- $\mathrm{C}_{\text {mic }}=\mu \mathrm{CO}_{2} \mathrm{~g}^{-1}$ soil $* 30$.

To quantify the efficiency of microbial respiration per unit biomass, the metabolic or respiratory quotient $\mathrm{q}\left(\mathrm{CO}_{2}\right)\left[\mathrm{mg} \mathrm{CO}_{2^{-}}\right.$ $\mathrm{C} \mathrm{h}^{-1} \mathrm{~g}^{-1}$ biomass SIR-C $\mathrm{C}_{\text {mic }}$ ] was calculated by dividing the BR by the SIR- $\mathrm{C}_{\text {mic }}$ (Anderson and Domsch, 1985): 
Biogeosciences Discuss., doi:10.5194/bg-2017-127, 2017

Manuscript under review for journal Biogeosciences

Discussion started: 3 May 2017

(c) Author(s) 2017. CC-BY 3.0 License.

$\mathrm{q}\left(\mathrm{CO}_{2}\right)=\frac{B R}{\mathrm{SIR}-\mathrm{C}_{\mathrm{mic}} / 1000}$

170 The higher the value of $\mathrm{q}\left(\mathrm{CO}_{2}\right)$, the higher the $\mathrm{CO}_{2}$ emissions per unit microbial biomass, indicating a lack of available $\mathrm{C}$ for metabolism in the soil.

\subsubsection{Degree of disturbance}

173 The present classification of anthropogenic disturbance is based on the mapped soil horizons from which the samples originated. The soil horizons and the degree of decomposition after von Post were mapped according to the German manual of soil mapping (Ad-Hoc-AG Boden, 2005). While the original von Post scale was developed for undrained peat, the German classification frequently uses the von Post scale for drained peat as well. The samples of peatland genesis were divided into five different disturbance classes according to the severity of disturbance and (Table 2, based on Ilnicki and Zeitz (2003) and Ad-Hoc-AG Boden (2005)): no disturbance (D0 (D0F/D0B), slight disturbance (D1F/D1B), moderate disturbance (D2F/D2B), strong disturbance (D3F) and heavy disturbance (D4F). Slightly disturbed horizons experience drainage and are influenced by a fluctuating water table, thus they are temporarily subjected to aerobic conditions but there has not yet been a secondary transformation of the peat structure. Earthified topsoils are defined as "moderately disturbed". Strong disturbance is characterised by blocky to prismatic aggregates and/or the formation of shrinkage cracks, and is only found in subsoils. In the present sample set, this level of disturbance only occurred in fen peat. Finally, both highly decomposed dusty "moorsh" and mixtures of peat and mineral soil have been defined as "heavily disturbed". This class also only occurred in fen peat. Overall there are five fen classes, three bog classes, and one class each for gyttja (organic or calcareous sediments) and other samples. Samples from the class other were organic marsh soils or could not be assigned to any disturbance class (e.g. buried organic soils). For further information see Table A1 in the appendix. Given that this classification was developed after the sample selection, the distribution among the groups is not uniform. The von Post scale from $\mathrm{H} 1$ to $\mathrm{H} 10$ was altered by adding $\mathrm{H} 11$ for low $\mathrm{C}$ organic soils deriving from peat. Gyttja and other remaining samples were not included in the van Post scale. 
Biogeosciences Discuss., doi:10.5194/bg-2017-127, 2017

Manuscript under review for journal Biogeosciences

Discussion started: 3 May 2017

(c) Author(s) 2017. CC-BY 3.0 License.

191 Table 2: Classification of the anthropogenic disturbance and corresponding median and standard error of soil properties: SOC: soil organic carbon content, C:Nratio: carbon to nitrogen ratio, $\delta^{15} \mathrm{~N}, \mathrm{~N}_{\mathrm{t}}$ : total nitrogen content, $\mathrm{P}_{\mathrm{CAL}}$ : calcium acetate lactate (CAL) extractable phosphorus content, pH-value, EC: electrical conductivity, $\mathrm{Fe}_{\mathrm{O}}$ : oxalate extractable iron content, $\rho$ : bulk density

\begin{tabular}{|c|c|c|c|c|c|c|c|c|c|c|c|c|c|}
\hline $\begin{array}{l}\text { Degree of } \\
\text { disturbance }\end{array}$ & Description & $\begin{array}{l}\text { Peatland } \\
\text { type }\end{array}$ & Label & $\mathrm{n}$ & $\begin{array}{c}\mathrm{SOC} \\
\left(\mathrm{g} \mathrm{kg}^{-1}\right)\end{array}$ & $\mathrm{C}: \mathrm{N}$ & $\begin{array}{l}\delta^{15} \mathrm{~N} \\
(\% 0)\end{array}$ & $\begin{array}{c}\mathrm{N}_{\mathrm{t}} \\
\left(\mathrm{g} \mathrm{kg}^{-1}\right)\end{array}$ & $\begin{array}{c}\mathrm{P}_{\mathrm{CAL}} \\
\left(\mathrm{mg} \mathrm{kg}^{-1}\right)\end{array}$ & $\mathrm{pH}$ & $\begin{array}{c}\mathrm{EC} \\
\left(\mu \mathrm{S} \mathrm{cm}^{-1}\right)\end{array}$ & $\begin{array}{c}\mathrm{Fe}_{\mathrm{O}} \\
\left(\mathrm{g} \mathrm{kg}^{-1}\right)\end{array}$ & $\begin{array}{c}\rho \\
\left(\mathrm{g} \mathrm{cm}^{-3}\right)\end{array}$ \\
\hline \multirow{2}{*}{$\begin{array}{c}\text { No } \\
\text { disturbance }\end{array}$} & \multirow{2}{*}{$\begin{array}{c}\text { Pristine or } \\
\text { nearly natural }\end{array}$} & Fen & $\mathrm{D} 0 \mathrm{~F}$ & 12 & $462 \pm 37$ & $23 \pm 3$ & $0.3 \pm 0.5$ & $19.4 \pm 2.6$ & $7.9 \pm 2.2$ & $5.5 \pm 0.4$ & $140 \pm 38$ & $5.5 \pm 1.1$ & $0.13 \pm 0.01$ \\
\hline & & Bog & D0B & 9 & $521 \pm 13$ & $57 \pm 8$ & $1.2 \pm 1.0$ & $9.1 \pm 2.4$ & $5.7 \pm 5.7$ & $3.2 \pm 0.1$ & $92 \pm 23$ & $0.9 \pm 1.7$ & $0.10 \pm 0.01$ \\
\hline \multirow{2}{*}{$\begin{array}{c}\text { Slight } \\
\text { disturbance }\end{array}$} & \multirow{2}{*}{$\begin{array}{l}\text { Alternating } \\
\text { aerobic- } \\
\text { anaerobic } \\
\text { conditions }\end{array}$} & Fen & $\mathrm{D} 1 \mathrm{~F}$ & 9 & $426 \pm 19$ & $18 \pm 4$ & $1.2 \pm 1.0$ & $21.8 \pm 2.0$ & $6.6 \pm 3.9$ & $5.2 \pm 0.4$ & $282 \pm 124$ & $13.4 \pm 2.7$ & $0.20 \pm 0.02$ \\
\hline & & Bog & D1B & 5 & $473 \pm 13$ & $46 \pm 7$ & $0.5 \pm 0.7$ & $10.7 \pm 1.5$ & $41.8 \pm 13.2$ & $3.5 \pm 0.1$ & $70 \pm 11$ & $3.3 \pm 2.8$ & $0.12 \pm 0.02$ \\
\hline \multirow{2}{*}{$\begin{array}{l}\text { Moderate } \\
\text { disturbance }\end{array}$} & \multirow{2}{*}{ Earthification } & Fen & $\mathrm{D} 2 \mathrm{~F}$ & 7 & $340 \pm 32$ & $17 \pm 1$ & $1.2 \pm 0.6$ & $21.0 \pm 1.9$ & $12.4 \pm 8.6$ & $5.2 \pm 0.2$ & $292 \pm 276$ & $21.0 \pm 4.7$ & $0.30 \pm 0.05$ \\
\hline & & Bog & D2B & 6 & $333 \pm 52$ & $23 \pm 2$ & $2.0 \pm 0.5$ & $14.2 \pm 2.6$ & $77.3 \pm 27.0$ & $3.8 \pm 0.3$ & $121 \pm 10$ & $9.3 \pm 1.8$ & $0.18 \pm 0.10$ \\
\hline $\begin{array}{c}\text { Strong } \\
\text { disturbance }\end{array}$ & $\begin{array}{l}\text { Polyhedral } \\
\text { aggregates or } \\
\text { cracks }\end{array}$ & Fen & D3F & 5 & $320 \pm 19$ & $14 \pm 1$ & $1.9 \pm 0.5$ & $24.0 \pm 1.8$ & $24.2 \pm 19.9$ & $5.6 \pm 0.6$ & $271 \pm 55$ & $24.4 \pm 14.1$ & $0.26 \pm 0.07$ \\
\hline $\begin{array}{c}\text { Heavy } \\
\text { disturbance }\end{array}$ & $\begin{array}{c}\text { Dusty } \\
\text { moorsh or } \\
\text { high content } \\
\text { of mineral } \\
\text { soil }\end{array}$ & Fen & $\mathrm{D} 4 \mathrm{~F}$ & 19 & $142 \pm 12$ & $14 \pm 1$ & $3.3 \pm 0.4$ & $10.0 \pm 1.1$ & $30.9 \pm 24.5$ & $5.4 \pm 0.3$ & $209 \pm 153$ & $19.6 \pm 2.7$ & $0.65 \pm 0.05$ \\
\hline Gyttja & $\begin{array}{l}\text { Organic or } \\
\text { calcareous } \\
\text { sediments }\end{array}$ & - & G & 12 & $100 \pm 19$ & $20 \pm 3$ & $1.7 \pm 0.6$ & $5.4 \pm 0.7$ & $14.2 \pm 7.5$ & $4.7 \pm 0.4$ & $253 \pm 206$ & $17.1 \pm 9.1$ & $0.51 \pm 0.08$ \\
\hline Other & $\begin{array}{l}\text { e.g. organic } \\
\text { marsh soils, } \\
\text { buried } \\
\text { horizons }\end{array}$ & - & $\mathrm{O}$ & 17 & $124 \pm 15$ & $16 \pm 2$ & $3.5 \pm 0.5$ & $7.0 \pm 0.7$ & $11.3 \pm 6.1$ & $5.2 \pm 0.3$ & $124 \pm 146$ & $21.8 \pm 3.9$ & $0.54 \pm 0.05$ \\
\hline
\end{tabular}


Biogeosciences Discuss., doi:10.5194/bg-2017-127, 2017

Manuscript under review for journal Biogeosciences

Discussion started: 3 May 2017

(c) Author(s) 2017. CC-BY 3.0 License.

\subsubsection{Statistical and multivariate analysis}

196

In a first step, Spearman's rank correlation coefficient $r_{s}$ was evaluated for the specific basal respiration and all measured explanatory variables using the R package "Hmisc" (Harrell, 2016). The p-values were adjusted using the method after Bonferroni. Differences between the results of disturbance classes for BR, SBR, SIR-C $\mathrm{Cmic}_{\text {and }} \mathrm{q}\left(\mathrm{CO}_{2}\right)$ were determined using an analysis of variance. P-values were computed with the Tukey 'honest significant differences' test $(\alpha=0.05)$ and adjusted with the Bonferroni correction using the R package "multcomp" (Hothorn et al., 2008). Correlation coefficients were classified as follows: $0.3 \geq r_{s} \geq 0.7$ is a moderate correlation and $r_{s}>0.7$ a strong correlation.

In a second step, multi-variate linear regression was applied to identify the most crucial factors and interactions influencing the specific basal respiration. The generalised least squares (gls) model was used with the exponential variance structure following the protocol of Zuur et al. (2009) using the R package "nlme" (Pinheiro et al., 2015). The SBR was set as the dependent variable, with the explanatory variables of SOC, $\mathrm{N}_{\mathrm{t}}, \mathrm{C}: \mathrm{N}-$ ratio, $\mathrm{P}_{\mathrm{CAL}}$, carbonate $\left(\mathrm{CaCO}_{3}\right), \mathrm{pH}, \delta^{13} \mathrm{C}, \delta^{15} \mathrm{~N}, \mathrm{Fe}_{\mathrm{O}}, \rho$, soil depth and EC as well as the categorical variables of the degree of decomposition (von Post, 1924), the degree of disturbance and peatland type. Important meaningful interactions were also incorporated. To achieve homoscedasticity of residuals, the data of $\mathrm{EC}$ and $\mathrm{P}_{\mathrm{CAL}}$ were $\log 10$ transformed and the $\mathrm{C}: \mathrm{N}$-ratio log-transformed. Applying the top-down strategy for the model selection, the complete generalised least squares model was run first and variables stepwise removed until all the variables were significant with a p-value $<0.001$ obtained by t-statistics. To identify the best model, Akaike's information criterion (AIC) was compared with the full model for all calculated models after each parameter drop. Afterwards, the best model was cross-validated using the "leave-one-site-out" approach.

All the results given below are medians with standard errors, unless otherwise stated. 
Biogeosciences Discuss., doi:10.5194/bg-2017-127, 2017

Manuscript under review for journal Biogeosciences

Discussion started: 3 May 2017

(c) Author(s) 2017. CC-BY 3.0 License.

\section{Results}

\subsection{Vulnerability of SOM as determined by respiration rates}

217 For all classes, BR was highly variable, ranging from 0.3 to $7.0 \mu \mathrm{g} \mathrm{CO}_{2}-\mathrm{C} \mathrm{g} \mathrm{soil}{ }^{-1} \mathrm{~h}^{-1}$ (Fig. 1a). The BR rates of fen samples decreased with an increasing degree of disturbance due to concomitantly decreasing SOC content (Table 2), while bog samples behaved inversely. Overall, bog samples $\left(2.0 \pm 0.3 \mu \mathrm{g} \mathrm{CO}_{2}-\mathrm{Cg} \mathrm{soil}{ }^{-1} \mathrm{~h}^{-1}\right)$ had similar $\mathrm{BR}$ rates to fen samples $\left(2.5 \pm 0.2 \mu \mathrm{g} \mathrm{CO}_{2}-\mathrm{C} \mathrm{g} \mathrm{soil}{ }^{-1} \mathrm{~h}^{-1}\right)$. Gyttja $\left(1.3 \pm 0.3 \mu \mathrm{g} \mathrm{CO}_{2}-\mathrm{C} \mathrm{g} \mathrm{soil}^{-1} \mathrm{~h}^{-1}\right)$ and other samples $\left(1.1 \pm 0.2 \mu \mathrm{g} \mathrm{CO}_{2}-\mathrm{C} \mathrm{g} \mathrm{soil}^{-1} \mathrm{~h}^{-1}\right)$ showed significantly lower BR rates than undisturbed, slightly and strongly disturbed fen samples (D0F, D1F, D3F). Overall, fen samples had significantly higher $(\mathrm{p}<0.01)$ average SBR rates of $8.3 \pm 0.7 \mu \mathrm{g} \mathrm{CO}_{2}-\mathrm{C} \mathrm{g} \mathrm{SOC}^{-1} \mathrm{~h}^{-1}$ than bog samples $\left(5.1 \pm 0.9 \mu \mathrm{g} \mathrm{CO}_{2}-\mathrm{C} \mathrm{g} \mathrm{SOC}{ }^{-1} \mathrm{~h}^{-1}\right)$. This difference was especially clear for undisturbed and slightly disturbed samples. SBR rates were also highly variable between and within classes, and ranging from 1.5 to $25.1 \mu \mathrm{g} \mathrm{CO}_{2}-\mathrm{C} \mathrm{g} \mathrm{SOC}^{-1} \mathrm{~h}^{-}$

${ }^{1}$ (Fig. 1b). SBR rates tended to increase with increasing soil disturbance for both fen and bog. D0B samples had significantly lower $(\mathrm{p}<0.01)$ SBR rates than the classes D4F, gyttja and other with $3.7 \pm 0.6 \mu \mathrm{g} \mathrm{CO}_{2}-\mathrm{C} \mathrm{g} \mathrm{SOC} \mathrm{g}^{-1}$. The moderately disturbed D2B samples showed much higher SBR rates $\left(10.1 \pm 2.1 \mu \mathrm{g} \mathrm{CO}_{2}-\mathrm{C}\right.$ g soil-SOC $\left.{ }^{-1} \mathrm{~h}^{-1}\right)$ than the other two bog classes, and were comparable to strongly and heavily disturbed fen samples (D3F, D4F). Both gyttja and other showed high and variable SBR rates with $14.2 \pm 2.4 \mu \mathrm{g} \mathrm{CO}_{2}-\mathrm{SOC} \mathrm{g} \mathrm{SOC}^{-1} \mathrm{~h}^{-1}$ and $10.8 \pm 1.5 \mu \mathrm{g} \mathrm{CO}_{2}-\mathrm{C} \mathrm{g} \mathrm{SOC}^{-1} \mathrm{~h}^{-1}$ respectively.

\subsection{Organic matter quality and soil characteristics determining SOM vulnerability}

The significant Spearman correlation coefficients indicated moderate positive correlations between SBR rates and phosphorus concentration $\left(r_{s}=0.52\right)$, pH value $\left(r_{s}=0.42\right)$, iron oxides $\left(r_{s}=0.42\right)$ and carbonate concentration $\left(r_{s}=0.36\right)$. Significant negative dependence was found between SBR and the C:N-ratio $\left(r_{s}=-0.62\right)$ and SOC content $\left(r_{s}=-0.49\right)$ (Fig. 2). The most influencing factors on SBR rates as indicated by the best fitted $g l s$ model were SOC, C:N-ratio, $\mathrm{P}_{\mathrm{CAL}}$ and $\rho$ (all $\mathrm{p}<0.001$ ). With these four parameters the cross-validated model explained $42 \%$ of the variability of the measured SBR rates.

While the correlation matrix shown in Fig. 2 gives a general overview on potential explanatory variables, a closer look is taken at some selected variables and their interaction with the disturbance classes (Figs. 3 and 4).

Overall, the variability and magnitude of SBR rates increased with decreasing SOC content (Fig. 3a) and an increasing degree of decomposition (Fig. 3b). The rates were highest and most variable for soil samples with a low SOC content, comprising the D4F, gyttja and other samples. Within disturbance classes, the strength of the negative correlations between SBR and SOC content tended to increase with increasing disturbance for fen peat, but became slightly positive for heavily disturbed D4F samples (Fig. 4). In contrast, bog, gyttja and other samples showed only weak correlations between SBR and SOC. 
Biogeosciences Discuss., doi:10.5194/bg-2017-127, 2017

Manuscript under review for journal Biogeosciences

Discussion started: 3 May 2017

(c) Author(s) 2017. CC-BY 3.0 License.
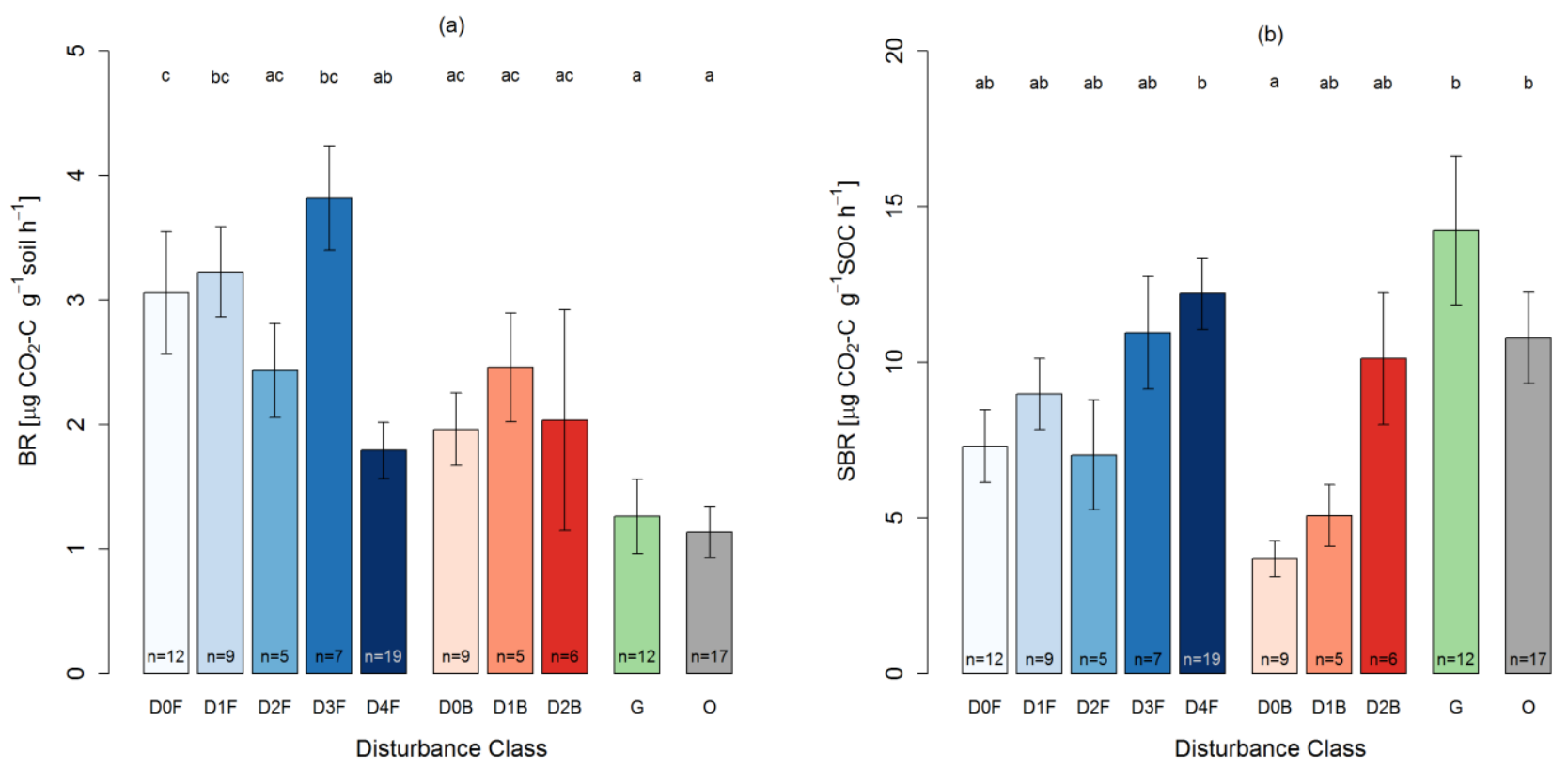

Figure 1: a) Median of basal respiration (BR) rates and b) specific basal respiration (SBR) rates for all disturbance classes: $F=f e n, B=b o g$, $\mathrm{G}=$ gyttja, $\mathrm{O}=$ other, $\mathrm{D} 0=$ no disturbance, $\mathrm{D} 1=$ slight disturbance, $\mathrm{D} 2=$ moderate disturbance, $\mathrm{D} 3=$ strong disturbance, $\mathrm{D} 4=$ heavy disturbance. Bars show the standard error. Different letters represent significant differences (Tukey's test, $\mathrm{p}<0.05$ ).

With increasing von Post values, SBR rates showed a significantly linear increase $(\mathrm{p}<0.001$, Fig. 3b). Soil samples with a von Post decomposition degree of $\mathrm{H} 3$ and $\mathrm{H} 7$ had significantly lower $(\mathrm{p}<0.05) \mathrm{SBR}$ rates of $6.3 \pm 1.0 \mu \mathrm{g} \mathrm{CO}_{2}-\mathrm{C} \mathrm{g} \mathrm{SOC}^{-1} \mathrm{~h}^{-1}$ and $7.8 \pm 0.8 \mu \mathrm{g} \mathrm{CO}_{2}-\mathrm{C} \mathrm{g} \mathrm{SOC}{ }^{-1} \mathrm{~h}^{-1}$, respectively, than samples mapped as $\mathrm{H} 10\left(13.4 \pm 1.2 \mu \mathrm{g} \mathrm{CO}_{2}-\mathrm{C} \mathrm{g} \mathrm{SOC}^{-1} \mathrm{~h}^{-1}\right)$. With decreasing C:N-ratios, SBR rates increased in an exponential manner (Fig. 3c). However, when splitting the samples into two groups at $\mathrm{C}: \mathrm{N}=25$, there was no longer any correlation for any of the groups. Again, the highest and most variable rates of $10.4 \pm 0.6 \mu \mathrm{g} \mathrm{CO}_{2}-\mathrm{C} \mathrm{g} \mathrm{SOC}{ }^{-1} \mathrm{~h}^{-1}$ were measured for highly disturbed samples with low $\mathrm{C}: \mathrm{N}$ ratios $<25$, which mainly belong to all fen classes, gyttja, D2B and other (see Table 2). In contrast, samples with a C:N-ratio $>25$ were bog samples with low or minimal disturbance, which had significantly lower $(\mathrm{p}<0.001)$ and less variable SBR rates of $4.1 \pm 0.6 \mu \mathrm{g} \mathrm{CO}_{2}-\mathrm{C} \mathrm{g} \mathrm{SOC}^{-1} \mathrm{~h}^{-1}$. In detail, there was a strong negative correlation between SBR rates and the C:N-ratio for D0F $\left(r_{s}=-0.73\right)$ and gyttja samples $\left(r_{s}=-0.85, p<0.05\right)$. Moderate correlations were found for other $\left(r_{s}=-0.56\right)$, D1F $\left(r_{s}=-\right.$ $0.47), \mathrm{D} 2 \mathrm{~F}\left(\mathrm{r}_{\mathrm{s}}=-0.32\right)$ and D0B $\left(\mathrm{r}_{\mathrm{s}}=-0.47\right)$ but these correlations were not significant (Fig. 4). 
Biogeosciences Discuss., doi:10.5194/bg-2017-127, 2017

Manuscript under review for journal Biogeosciences

Discussion started: 3 May 2017

(c) Author(s) 2017. CC-BY 3.0 License.

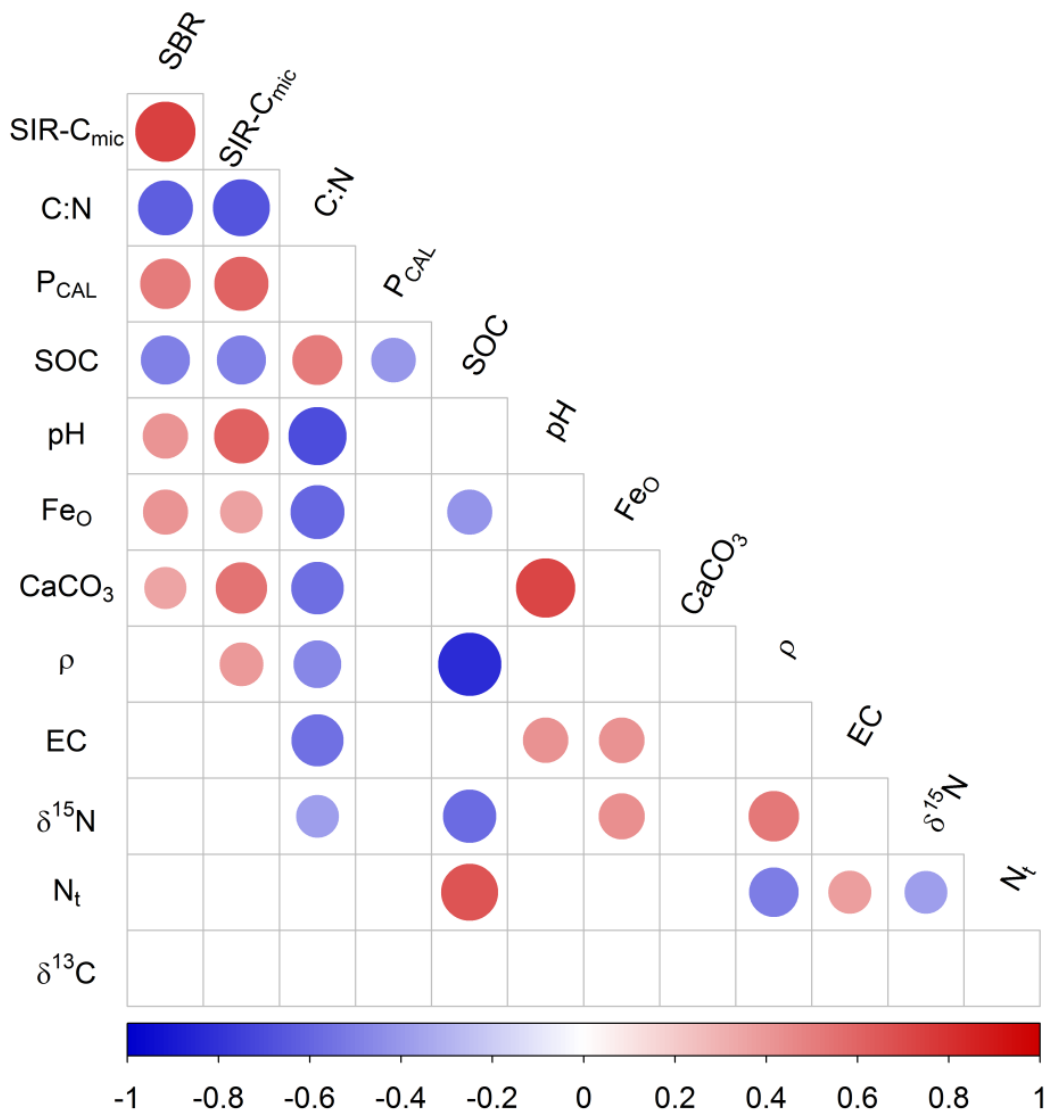

Figure 2: Significant $(\mathrm{p}<0.05)$ correlation coefficients after Spearman for the specific basal respiration rates $(\mathrm{SBR})$ as well as the determined specific microbial biomass $\left(\mathrm{SIR}-\mathrm{C}_{\text {mic }}\right.$ ) and all determined soil properties: $\mathrm{C}: \mathrm{N}$-ratio: carbon to nitrogen ratio, $\mathrm{P}_{\mathrm{CAL}}$ : calcium acetate lactate (CAL) extractable phosphorus content, $\mathrm{SOC}$ : soil organic carbon content, $\mathrm{pH}$-value, $\mathrm{Fe}_{\mathrm{O}}$ : oxalate extractable iron content, $\mathrm{CaCO}_{3}$ : calcium carbonate content, $\rho$ : bulk density, EC: electrical conductivity, $\delta^{15} \mathrm{~N}, \mathrm{~N}_{\mathrm{t}}$ : total nitrogen content and $\delta^{13} \mathrm{C}$

Even though there was no general relationship between $N_{t}$ and SBR rates (Fig. 3d), $N_{t}$ concentrations were positively correlated with the respiration rates of the disturbance classes D0F $\left(\mathrm{r}_{\mathrm{s}}=0.57\right), \mathrm{D} 4 \mathrm{~F}\left(\mathrm{r}_{\mathrm{s}}=0.37\right), \mathrm{D} 0 \mathrm{~B}\left(\mathrm{r}_{\mathrm{s}}=0.47\right)$ and gyttja samples $\left(r_{\mathrm{s}}=0.55\right)\left(\right.$ Fig. 4). In contrast, the samples of D3F $\left(r_{s}=-0.6\right)$ were negatively correlated.

There was a significant $(\mathrm{p}<0.001)$ difference in $\delta^{15} \mathrm{~N}$ values between samples from undisturbed and disturbed horizons (Fig. 3e). The mean values for undisturbed horizons were $0.0 \pm 0.6 \%$ (D0B) and $-0.3 \pm 0.4 \%$ (D0F) respectively. All the other disturbance classes showed higher $\delta^{15} \mathrm{~N}$ values up to $11.2 \%$, and a slight overall increase in SBR rates with increasing $\delta^{15} \mathrm{~N}$. However, mainly within (relatively) undisturbed classes, there were negative correlations between $\delta^{15} \mathrm{~N}$ and SBR rates for D0B $\left(r_{s}=-0.5\right)$, D1B $\left(r_{s}=-0.7\right)$ and D3F $\left(r_{s}=-0.3\right)($ Fig. 4). In contrast, there were slightly positive correlations in the case of heavily disturbed D4F samples $\left(\mathrm{r}_{\mathrm{s}}=0.33\right)$. variable with the highest number of positive correlations with SBR over all disturbance classes. This is visualised by the 
Biogeosciences Discuss., doi:10.5194/bg-2017-127, 2017

Manuscript under review for journal Biogeosciences

Discussion started: 3 May 2017

(c) Author(s) 2017. CC-BY 3.0 License.

276 linear increase of SBR with $\mathrm{P}_{\mathrm{CAL}}$ (Fig. 3f). In the case of bogs, the correlation increased with increasing disturbance (D0B:

$277 r_{s}=0.42$, D1B: $r_{s}=0.5$, D2B: $r_{s}=0.77$, Fig. 4). Overall the bog samples $\left(r_{s}=0.71, p<0.05\right)$ had a significantly strong 278 dependence and the fen samples $\left(r_{s}=0.49, p<0.01\right)$ a significantly moderate dependence on $\mathrm{P}_{\mathrm{CAL}}$. The effect of the 279 disturbance class was less consistent in the case of fens compared to bogs, with the strongest correlation in D3F $\left(r_{\mathrm{s}}=1\right.$, $280 \mathrm{p}<0.001)$.

281 Considering all the samples, SBR rates increased linearly with increasing pH (Fig. $3 \mathrm{~g}$ ), reflecting the general differences 282 between bogs and fens. This increase in SBR was most distinctive for D0F $\left(\mathrm{r}_{\mathrm{s}}=0.85, \mathrm{p}<0.05\right)$, D1B $\left(\mathrm{r}_{\mathrm{s}}=0.5\right)$ and $g y t$ tja 283 samples $\left(r_{\mathrm{s}}=0.78\right)$. The correlation with $\mathrm{pH}$ values was moderate for $\mathrm{D} 0 \mathrm{~B}\left(\mathrm{r}_{\mathrm{s}}=0.47\right)$, other $\left(\mathrm{r}_{\mathrm{s}}=0.37\right)$ and $\mathrm{D} 2 \mathrm{~F}$ samples $284\left(r_{s}=-0.46\right)$, which were negatively correlated (Fig. 4). Overall, the SBR rates of bog samples correlated strongly with pH $285\left(\mathrm{r}_{\mathrm{s}}=0.74, \mathrm{p}<0.05\right)$, even though bog samples covered only a small range $(3.5 \pm 0.1)$ of the overall pH values, whereas other 286 samples had the widest range $(5.2 \pm 0.3)$ followed by gyttja $(4.8 \pm 0.4)$ and fen samples $(5.6 \pm 0.2)$.

287 The concentration of iron oxides had a linear positive relationship with SBR rates (Fig. 2), which was especially noticeable 288 in the strong correlation with D2F samples $\left(r_{s}=0.96, p<0.05\right)$. Furthermore, rates of D1F $\left(r_{s}=0.37\right)$, D1B $\left(r_{s}=0.4\right)$ and 289 other samples $\left(r_{s}=0.36\right)$ showed moderate positive dependence on Fe $($ Fig. 3h; Fig. 4). However, this effect was not 290 systematic as the SBR rates of samples of disturbance class D3F $\left(r_{s}=-0.5\right)$ were negatively correlated with iron 291 concentration. 
Biogeosciences Discuss., doi:10.5194/bg-2017-127, 2017

Manuscript under review for journal Biogeosciences

Discussion started: 3 May 2017

(c) Author(s) 2017. CC-BY 3.0 License.

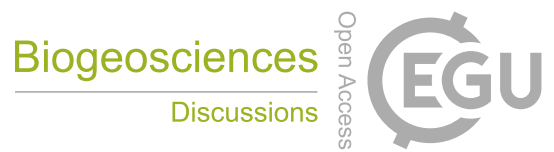

(c) (i)
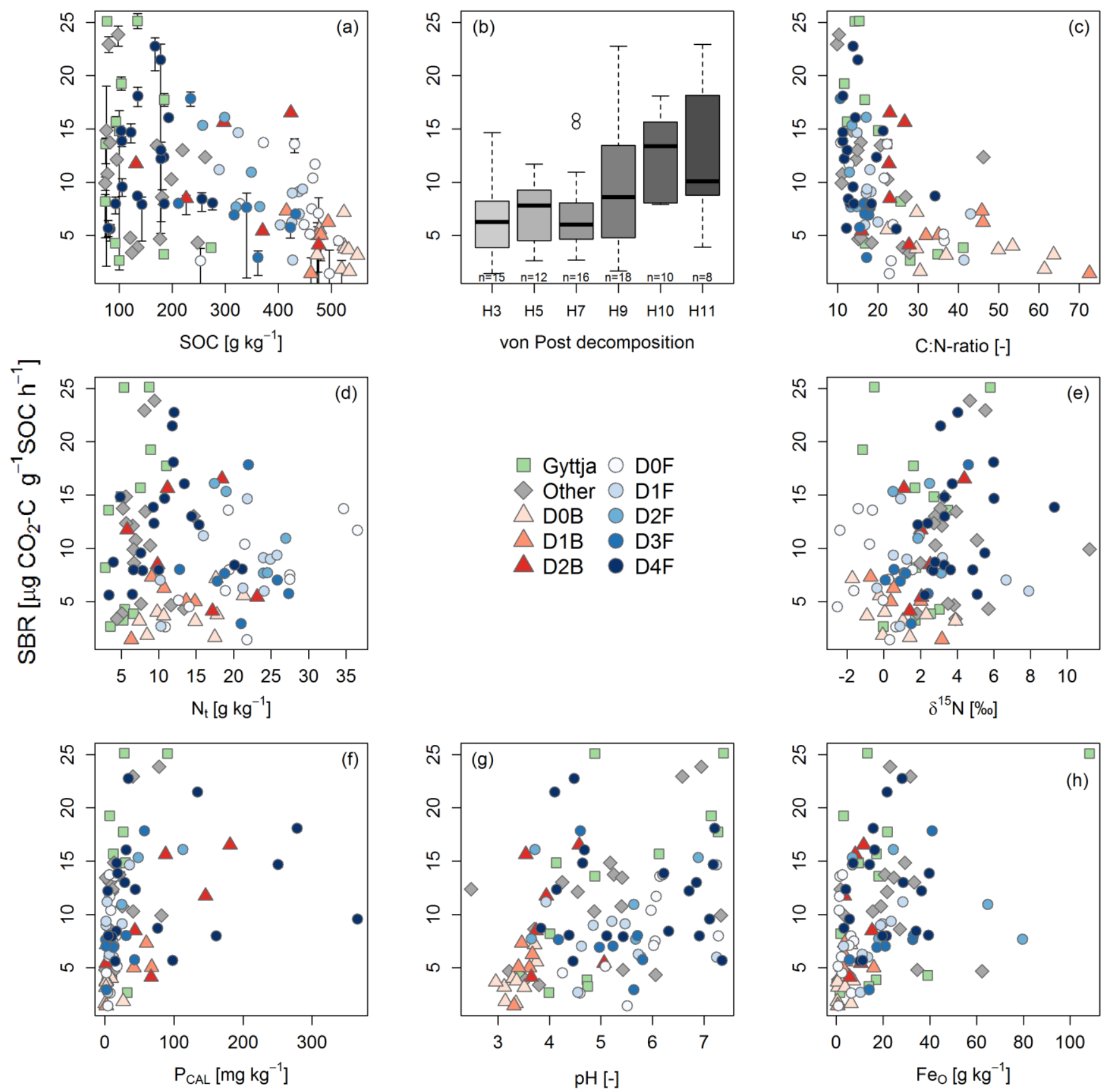

Figure 3: Specific basal respiration (SBR) rates of all samples classified in disturbance classes ( $F=f e n, B=b o g, G=g y t t j a, ~ O=o t h e r, ~ D 0=n o$ disturbance, D1=slight disturbance, D2=moderate disturbance, D3=strong disturbance, D4=heavy disturbance) versus (a) soil organic carbon content, (b) decomposition degree after von Post, (c) carbon-to-nitrogen ratio, (d) total nitrogen content, (e) $\delta^{15} \mathrm{~N}$, (f) calcium acetate lactate (CAL) extractable phosphorus content, (g) pH value, (h) oxalate extractable iron content. Bars in (a) show 2.5 and $97.5 \%$ quantiles of the DREAM-fit. 
Biogeosciences Discuss., doi:10.5194/bg-2017-127, 2017

Manuscript under review for journal Biogeosciences

Discussion started: 3 May 2017

(c) Author(s) 2017. CC-BY 3.0 License.

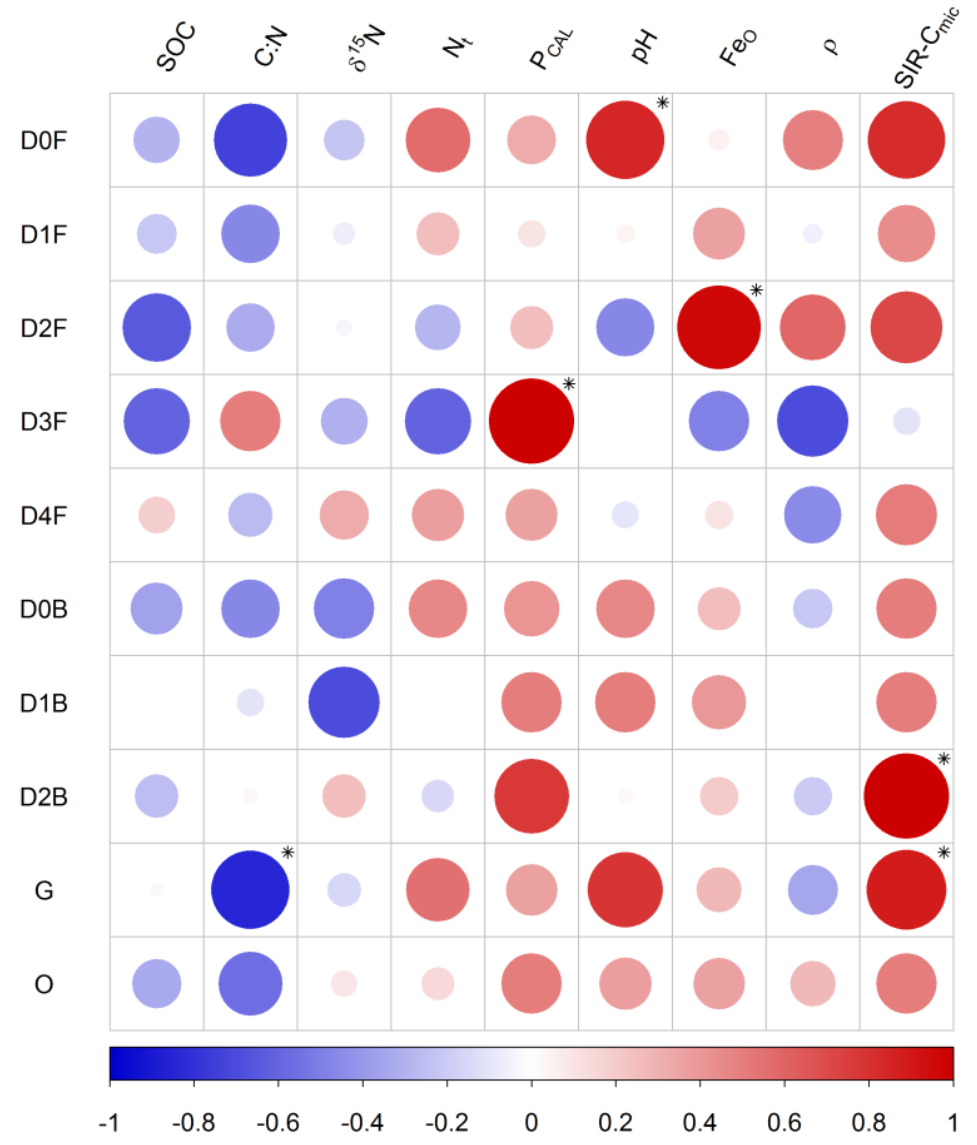

Figure 4: Correlation coefficients after Spearman (significant correlations $(\mathrm{p}<0.05)$ are marked with asterisks) for the specific basal respiration rates separated into the disturbance classes $(\mathrm{F}=\mathrm{fen}, \mathrm{B}=\mathrm{bog}, \mathrm{G}=\mathrm{gyttja}, \mathrm{O}=\mathrm{other}, \mathrm{D} 0=$ no disturbance, $\mathrm{D} 1=$ slight disturbance, $\mathrm{D} 2=$ moderate disturbance, $\mathrm{D} 3=$ strong disturbance, $\mathrm{D} 4=$ heavy disturbance) and soil properties: SOC: soil organic carbon content, $\mathrm{C}: \mathrm{N}$ ratio: carbon to nitrogen ratio, $\delta^{15} \mathrm{~N}, \mathrm{~N}_{\mathrm{t}}$ : total nitrogen content, $\mathrm{P}_{\mathrm{CAL}}$ : calcium acetate lactate $(\mathrm{CAL})$ extractable phosphorus content, $\mathrm{pH}-$ value, $\mathrm{Fe}_{\mathrm{O}}$ : oxalate extractable iron content, $\rho$ : bulk density, as well as the determined specific microbial biomass $\left(\mathrm{SIR}-\mathrm{C}_{\mathrm{mic}}\right)$

\subsection{Relation between microbial biomass and mineralisation rates}

Overall, the specific microbial biomass (Fig. 5a) was positively correlated with SBR $\left(\mathrm{r}_{\mathrm{s}}=0.75\right)$ and thus followed a similar pattern to SBR (Fig. 1b) across disturbance classes: values were higher for fen samples than for bog samples and tended to increase with increasing disturbance, especially in the case of bog samples. There were strong positive correlations between SIR- $\mathrm{C}_{\mathrm{mic}}$ and SBR for all disturbance classes (Fig. 4), except D2F $\left(\mathrm{r}_{\mathrm{s}}=0.45\right)$, which was moderately correlated with SIR-C $\mathrm{C}_{\mathrm{mic}}$ and D3F. Samples of the classes D2B $\left(\mathrm{r}_{\mathrm{s}}=1, \mathrm{p}<0.001\right)$ and gyttja $\left(\mathrm{r}_{\mathrm{s}}=0.88, \mathrm{p}<0.05\right)$ showed the highest dependencies. Overall, specific SIR-C $C_{\text {mic }}$ was highest for D4F samples $\left(3249 \pm 411 \mu \mathrm{g} \mathrm{C} \mathrm{g}^{-1}\right.$ SOC) followed by D3F (2293 $\pm 612 \mu \mathrm{g} \mathrm{C} \mathrm{g}^{-}$ $\left.{ }^{1} \mathrm{SOC}\right)$ and D2B samples $\left(2265 \pm 400 \mu \mathrm{g} \mathrm{Cg}^{-1} \mathrm{SOC}\right)$. Gyttja $\left(1907 \pm 339 \mu \mathrm{g} \mathrm{C} \mathrm{g}^{-1} \mathrm{SOC}\right)$ and other samples 
Biogeosciences Discuss., doi:10.5194/bg-2017-127, 2017

Manuscript under review for journal Biogeosciences

Discussion started: 3 May 2017

(c) Author(s) 2017. CC-BY 3.0 License.

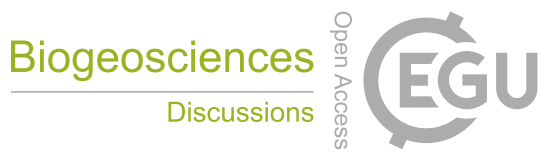

$312\left(1528 \pm 533 \mu \mathrm{g} \mathrm{C} \mathrm{g}^{-1}\right.$ SOC) had relatively high values of microbial specific SIR-C $\mathrm{m}_{\mathrm{mic}}$, with the latter being the most variable 313 of all the groups.

314 Specific SIR-C ${ }_{\text {mic }}$ showed similar relationships with explanatory variables as SBR (Fig. 2).

315 There were no significant differences in the metabolic quotient between disturbance classes (Fig. 5b). The values of the 316 classes D0F, D1F, D2F, D4F and D2B were slightly lower than those of the other classes, and there was a slight tendency for 317 a decreasing metabolic quotient with increasing disturbance for bog samples.
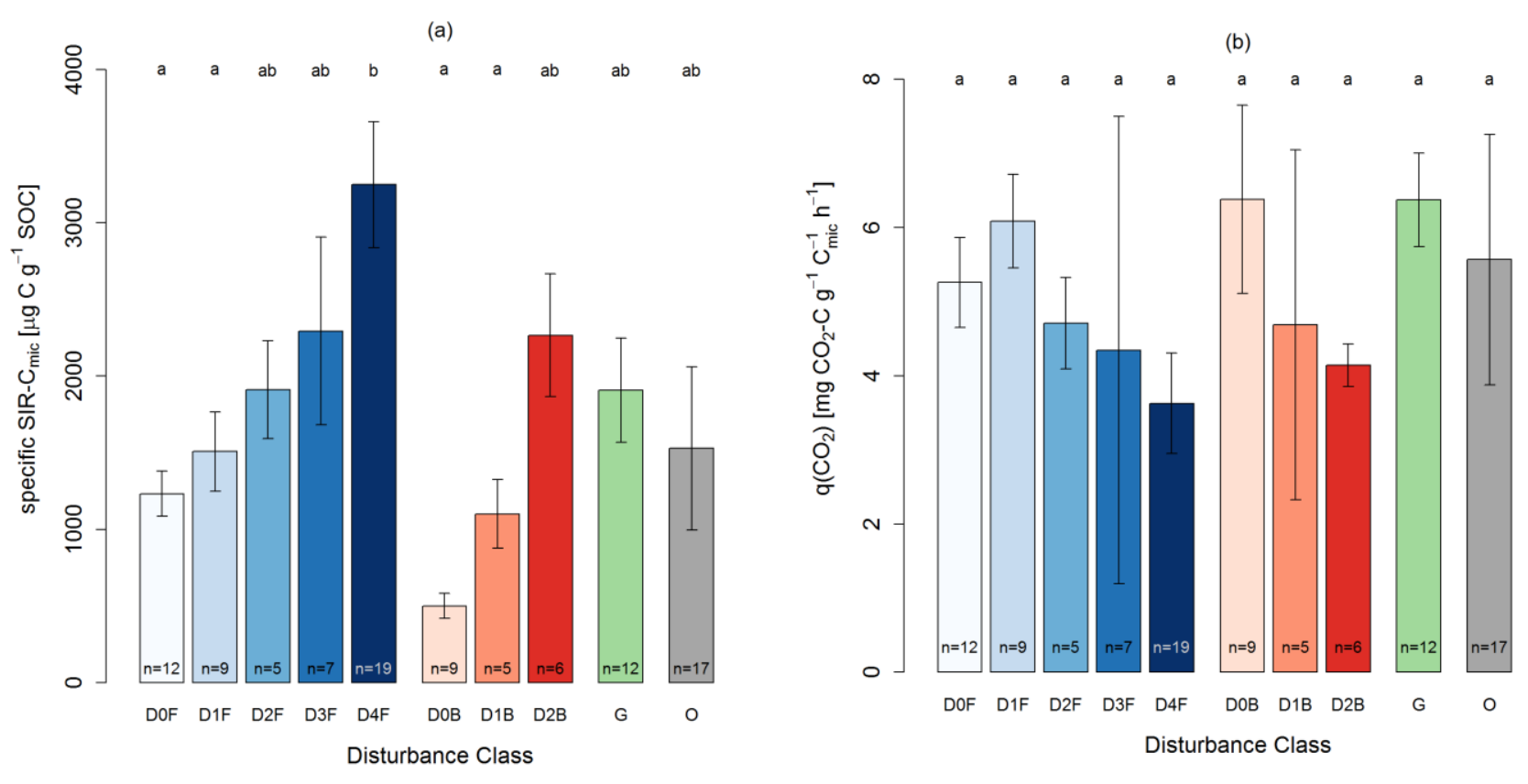

Figure 5: a) Median of specific microbial biomass (SIR- $\mathrm{C}_{\text {mic }}$ ) determined via substrate induced respiration (SIR) and b) metabolic quotient $\left(\mathrm{q}\left(\mathrm{CO}_{2}\right)\right)$ for different disturbance classes: $\mathrm{F}=\mathrm{fen}, \mathrm{B}=\mathrm{bog}, \mathrm{G}=\mathrm{gyttja}, \mathrm{O}=$ other, $\mathrm{D} 0=$ no disturbance, $\mathrm{D} 1=$ slight disturbance, $\mathrm{D} 2=$ moderate disturbance, D3=strong disturbance, D4=heavy disturbance. Bars show the standard error. Different letters represent significant differences 
Biogeosciences Discuss., doi:10.5194/bg-2017-127, 2017

Manuscript under review for journal Biogeosciences

Discussion started: 3 May 2017

(c) Author(s) 2017. CC-BY 3.0 License.

\section{Discussion}

325

326

327

328

329

330

331

332

333

334

335

336

337

338

339

340

341

342

343

344

345

346

347

348

349

350

351

352

353

354

355

\subsection{Enhanced SOM vulnerability to decomposition with increasing disturbance of peat}

The most striking result of the present experiment was that specific basal respiration rates increased both in magnitude and variability with increasing degradation and disturbance of the peat soils, irrespective of whether this degradation was expressed as a von Post value, a disturbance class or SOC content (Figs. 3 and 4). This finding was best illustrated in the bog samples and manifested itself in the more variable specific basal respiration rates with a smaller SOC content. Second, in contrast to less disturbed peat samples, it proved to be practically impossible to describe the specific basal respiration or specific microbial biomass for heavily disturbed fen samples with the set of explanatory variables used here (Fig. 4). In contrast to specific basal respiration, it is noteworthy that the basal respiration rates tended to increase with increasing disturbance for bog samples, while there was a significant decrease for fen samples, i.e. the effects of disturbance on total basal respiration were soil specific (Fig. 1a).

Glatzel et al. (2004) refer to the importance of the von Post value as an indicator of $\mathrm{CO}_{2}$ production, however they identified a negative correlation. Similarly Ilnicki and Zeitz (2003) found lower $\mathrm{CO}_{2}$ production rates for samples with a high degree of decomposition and the lowest rates for moorshy peat soils. However, Brake et al. (1999) found increasing specific basal respiration rates for increasingly disturbed peat samples. The most probable reason for the discrepancies is that the von Post scale was originally developed for natural peatlands, where strong decomposition is caused by age as well as climatic conditions during peat formation and peatland development, and not by anthropogenic impacts. Due to the lack of better, widely accepted indicators, the von Post scale is frequently applied to drained peatlands as well. Consequently, the naturally strongly decomposed peat of the study of Glatzel et al. (2004) underwent a completely different pedogenesis than the samples from the drained peatlands in the present study. With regard to the results of Ilnicki and Zeitz (2003), the high variability in the specific basal respiration of the strongly disturbed samples in the present study also includes "moorshy" samples with low respiration rates.

The higher specific basal respiration rates of fen samples compared to bog samples of similar disturbance, has been observed in previous studies (e.g. Bridgham and Richardson, 1992; Urbanova and Barta, 2015) and was expected here. Generally, faster decomposition processes occur under minerotrophic conditions and in peat dominated by vascular plants (Blodau, 2002). Undisturbed bogs are characterised by a lack of nutrients, strong acidity and peat substrates that hinder rapid mineralisation due to their chemical composition (Urbanová and Bárta, 2014; Verhoeven and Liefveld, 1997).

It has been found that after drainage the microbial communities increase in richness and diversity in bogs, but in contrast decrease for fens (Urbanová and Bárta, 2015), indicating the high sensitivity of bogs to anthropogenic impacts. The same authors also found that fens and bogs become more similar after long-term drainage as their characteristic differences in biogeochemical properties and microbial composition reduce. This could explain our observation that strong disturbance diminished differences in specific basal respiration rates between bog and fen peat. Additionally, increased nutrient supply 
Biogeosciences Discuss., doi:10.5194/bg-2017-127, 2017

Manuscript under review for journal Biogeosciences

Discussion started: 3 May 2017

(c) Author(s) 2017. CC-BY 3.0 License.

(Wells and Williams, 1996) and effects of physical disturbance (Ross and Malcolm, 1988; Rovdan et al., 2002) might contribute to this effect. Furthermore disturbance might reactivate enzymes that were previously inactive, thus enhancing mineralisation rates under favourable conditions (Freeman et al., 1996, 2001). Freeman et al. (2001) found that the enzyme phenol oxidase has a tremendous effect on increasing the peat decomposition under aerobic conditions. These effects might cause the strong increase in specific basal respiration rates and specific microbial biomass values from undisturbed/slightly disturbed to moderately disturbed bog samples.

Surprisingly, gyttja and other organic soils showed similarly high specific basal respiration rates as the heavily disturbed peat samples. To the authors' knowledge, there are no studies that have determined the respiration rates of gyttja before, as gyttja soils are most often covered by peat soils. However, organic gyttja soils have similar physical soil properties to heavily disturbed peat, including high bulk density, a high degree of decomposition and low pore volume (Chmieleski, 2006). Intensive microbial processes in drained organic gyttja soils as well as the presence of easily degradable SOM (Chmieleski, 2006) could explain the high respiration rates.

Overall, the structural and chemical changes of the peat properties seems to cause destabilising positive feedback processes, as shown in specific basal respiration and, in the case of bogs, the absolute values of respiration increase as well.

\subsection{SOM quality as an indicator of SOM vulnerability}

While SOM quality is closely linked to the mineralisation of SOM, there is no commonly accepted quality index for SOM (Reiche et al., 2010). To characterise SOM quality, C:N-ratio, degree of decomposition and $\delta^{15} \mathrm{~N}$ stable isotope values were used in this study, as they are all indicators of the transformation stage of organic matter (Bohlin et al., 1989; Glatzel et al., 2004; Krüger et al., 2014; Reiche et al., 2010). The results pointed to a faster turnover of SOM in samples with a narrow $\mathrm{C}: \mathrm{N}$-ratio, especially in fen samples. Specific basal respiration rates increased rapidly with falling C:N-ratios below a threshold value of 25 (Fig. 3c). However this may only be an effect of preferential C release during decomposition at sufficient $\mathrm{N}$ supply (Kuhry and Vitt, 1996), i.e. a narrow C:N-ratio is also a product of fast turnover. In contrast, wider C:Nratios seem to indicate a more stable SOM pool. This indicates that there is surprisingly no increased stabilisation with increased degradation due to selective preservation of more stable SOC components (Lehmann and Kleber, 2015) that are unattractive for decay, such as waxes, polyphenols, lignins and tannins (Verhoeven and Liefveld, 1997). Low $\delta^{15} \mathrm{~N}$ values appear to be a good indicator of undisturbed or fresh SOM, especially in bog peat, due to the lack of SOM turnover processes that usually result in ${ }^{15} \mathrm{~N}$ enrichment (Nadelhoffer et al., 1996). For the increasingly disturbed samples, the correlation between specific basal respiration and $\delta^{15} \mathrm{~N}$ became positive (Fig. 4), indicating that increased microbial transformation under aerobic conditions altered the stable isotope signature of SOM. Mineralisation will therefore result in both increased $\delta^{15} \mathrm{~N}$ values and increased respiration rates, making it difficult to distinguish between cause and effect.

Overall, the greater the disturbance, the harder it proved to be to find possible patterns of SOM quality parameters and specific basal respiration, especially in the case of fen samples. One reason for this could be that chemical and physical 
Biogeosciences Discuss., doi:10.5194/bg-2017-127, 2017

Manuscript under review for journal Biogeosciences

Discussion started: 3 May 2017

(c) Author(s) 2017. CC-BY 3.0 License.

changes during decomposition differ between peat-forming plants (Bohlin et al., 1989), that can no longer be identified and are more diverse in bogs than in fens. Furthermore, the class of heavily disturbed fen samples combines samples which have been amended by mineral soil by different processes (e.g. ploughing, application from external sources, or natural sedimentation in riverine fens) and those which have become "moorshy", but were not amended. To disentangle different processes, a larger number of samples and more detailed information on the sites' history will be required in future studies. Finally, the DREAM-fits showed the largest uncertainty for some of the samples of the class D4F (Fig. 3a), which might have contributed to the difficulty in finding appropriate explanatory variables.

\subsection{Nutrients and acidity as indicators of SOM vulnerability}

Agriculturally used peats drained for a long time are often enriched in N and (labile) P concentrations (Laiho et al., 1998; Schlichting et al., 2002; Sundström et al., 2000) due to ongoing mineralisation of SOM and sorption of the resulting inorganic P forms to Fe(III) compounds (Zak et al., 2010). As P is needed for microbial growth, a lack of labile phosphorus limits the decomposition of SOM, and this limitation may be due to both low P contents as well as sorption and fixation of $\mathrm{P}$ to iron, calcium or aluminium minerals (Wells and Williams, 1996). This was also the case in the present sample set (Table 2). The results of the present study show that plant-available phosphorus $\left(\mathrm{P}_{\mathrm{CAL}}\right)$ was the most important explanatory variable for specific basal respiration rates, especially for bog samples. This confirms the results of Brake et al. (1999) who also found that $\mathrm{P}$ strongly correlates with the respiration rates of disturbed bog samples. Due to the low $\mathrm{pH}$ and iron concentrations, bogs are frequently P-limited (Verhoeven et al., 1990), which is reflected in the correlation between specific basal respiration and $\mathrm{P}_{\mathrm{CAL}}$ (Fig. 4) Depending on the iron concentration (Zak et al., 2010), deeper and less disturbed peat layers are potentially threatened by enhanced $\mathrm{P}$ mobilisation and leaching.

Nitrogen concentrations only increased for moderately disturbed bog samples, and even decreased for heavily disturbed fen samples compared to undisturbed or slightly disturbed samples (Table 2). This might be due to accelerated N-mineralisation (Williams and Wheatley, 1988) or increased immobilisation of $\mathrm{N}$ since peat plants are decomposed under increasing oxygen supply and disturbance levels (Wells and Williams, 1996). As indicated by the correlations (Fig. 4) specific basal respiration rates seem only to be positively influenced by $\mathrm{N}$ concentrations in the case of undisturbed samples and gyttja. Gyttja samples are fairly undisturbed in most cases too, due to the soil depth. This might indicate a shift from $\mathrm{N}$ to $\mathrm{P}$ limitation in the course of degradation processes since ongoing mineralisation increases the N supply. Furthermore Toberman et al. (2015) found a positive correlation between $\mathrm{N}$ and $\mathrm{P}$ content in Sphagnum peat, pointing to the important role of $\mathrm{P}$ availability in $\mathrm{N}$ fixation. Beside nutrient impacts, there was also a positive correlation between specific basal respiration rates and the $\mathrm{pH}$ of gyttja, undisturbed fen and bog and slightly disturbed bog samples, probably reflecting lower microbial activity in an acidic environment (Fig. 5a). The present study's findings of a positive relationship between specific basal respiration rates and $\mathrm{pH}$ value of undisturbed, slightly and moderately disturbed peat samples (Figs. 2 and 3g) are in an apparent contradiction to earlier reports that have detected a negative correlation (Ausec et al., 2009; Fisk et al., 2003). The authors explain the 
Biogeosciences Discuss., doi:10.5194/bg-2017-127, 2017

Manuscript under review for journal Biogeosciences

Discussion started: 3 May 2017

(c) Author(s) 2017. CC-BY 3.0 License.

negative relationship by a restricted efficiency of $\mathrm{C}$ metabolism of the microbial biomass in bogs due to the acidic environment, which was however not the case in the present study's samples set (see section 4.4; Fig. 5b), and contradict the common observation that bogs show higher respiration rates than fens (e.g. Bridgham and Richardson, 1992; Urbanova and Barta, 2015). Although all three studies used undisturbed peatland sites, their samples had a smaller pH range and they only sampled to a depth of $30 \mathrm{~cm}$, instead of up to $200 \mathrm{~cm}$ as in the present study. This and the fact that a broader sampling site basis was used here could explain the contrasting correlation. However, with increasing disturbance the influence of $\mathrm{pH}$ diminishes in the present samples, possibly due to better nutrient availability and increased pH-values overall in bogs. As already mentioned, it was impossible to identify any strong correlations between soil properties and specific basal respiration or SIR-C $\mathrm{C}_{\text {mic }}$ of heavily disturbed fens samples (D4F Fig. 4). Since these soils have a comparably low SOC content (142 $\pm 12 \mathrm{~g} \mathrm{~kg}^{-1}$, Table 2), they have become increasingly similar to mineral soils. It could therefore be expected that stabilisation mechanisms for $\mathrm{SOM}$ become more similar to mineral soils. However, $\mathrm{Fe}_{\mathrm{O}}$, which has been shown to be important for SOM stabilisation (Wagai and Mayer, 2007 and references therein), is of minor importance for specific basal respiration, even for samples at the boundary of mineral and organic soils (Fig. 4). Furthermore, numerous studies have shown SOM stabilisation on clay minerals (e.g. Hassink, 1997; Saidy et al., 2012; Six et al., 2016). However, there was no correlation between clay content and specific basal respiration in the present set of samples, despite the wide range of clay content in the heavily disturbed samples (5-50\%).

\subsection{Microbial biomass and activity}

The specific microbial biomass increased with the increasing degree of anthropogenic disturbance for both fen and bog samples (Fig. 5a). This is surprising since highly degraded peat should be energetically less attractive for microorganisms than well conserved peat (Fisk et al., 2003). The transition from anaerobic to aerobic conditions increases mineralisation (Bridgham and Richardson 1992; Glatzel et al. 2004; Holden et al. 2004 and references therein), and therefore improves the availability of nutrients as well as readily available SOM since fertilisation causes changes in the community and in the amount of microbial biomass (Amador and Jones, 1993; Brouns et al., 2016). This is reflected in positive correlations of specific microbial biomass with $\mathrm{pH}$ value and negative correlations with $\mathrm{C}: \mathrm{N}$-ratios. The metabolic quotient, i.e. the ratio of basal respiration and microbial biomass, indicates the efficiency of microorganisms to transform SOM into microbial biomass. Overall, there were no significant differences in the metabolic quotient between disturbances classes (Fig. 5b). However, gyttja and other samples have a high potential of respiring $\mathrm{CO}_{2}$ although they have low microbial biomass and SOC contents. In contrast, the slight tendency towards lower metabolic quotients of strongly disturbed bog and fen samples compared to undisturbed samples indicate that these microorganisms are more efficient at using SOM for growth. Although the metabolic quotients were lower compared to the undisturbed samples, the high amount of microbial active biomass and the high specific respiration rates point towards accelerated mineralisation rates in the strongly and heavily disturbed peat samples. 
Biogeosciences Discuss., doi:10.5194/bg-2017-127, 2017

Manuscript under review for journal Biogeosciences

Discussion started: 3 May 2017

(c) Author(s) 2017. CC-BY 3.0 License.

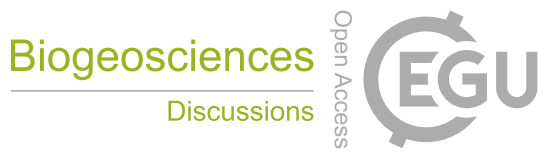

(c) (i)

\section{$452 \quad 4.5 \quad$ Implications for peatland management}

453 The high specific basal respiration rates of heavily disturbed samples confirm the vulnerability of "low C organic soils" that 454 has already been identified in field studies (Leiber-Sauheitl et al., 2014; Tiemeyer et al., 2016). Potential emissions do not 455 reach a constant level, and do not always decrease or stop with increasing disturbance. The SOC content below which such 456 soils behave like mineral soils does not seem to be within the studied SOC range. However, there were heavily disturbed 457 samples in this present study that showed low potential emissions which agrees with the finding that the variability of $\mathrm{CO}_{2}$ 458 emissions from "low C organic soils" field studies is high. Therefore mixing organic soil with mineral soil does not seem to 459 mitigate respiration rates by the potential stabilisation effect of clay, but on average increases the vulnerability of SOM. 460 However, for specific samples the respiration rates are still rather unpredictable. By ploughing mineral soil into the peat 461 layer, a whole new soil horizon develops, that may include modified microbial communities and potentially fresh SOM after 462 disaggregation of the peat takes place (Ross and Malcolm, 1988). Applying N and especially P fertilisers on peatlands might 463 increase the specific basal respiration rates (Amador and Jones, 1993), because lower respiration rates of less disturbed peat 464 samples might be primarily caused by their nutrient limitation. However, it should be stressed that additional experiments 465 that could provide clearer answers to such questions were not carried out. Similarly, liming of acidy peat soils might have a 466 similar effect because increasing the $\mathrm{pH}$ value generates favourable microbial conditions for decomposition (Andersson and 467 Nilsson, 2001; Fuentes et al., 2006). Finally, degradation of the topsoil might even influence the mineralisation of deeper 468 peat layers due to leaching of nutrients and dissolved organic matter. Rising water tables may prevent further decomposition 469 and reinstate the typical peatland environment, however severe disturbance might have a long-lasting effect on the 470 biogeochemistry of rewetted peatlands. 
Biogeosciences Discuss., doi:10.5194/bg-2017-127, 2017

Manuscript under review for journal Biogeosciences

Discussion started: 3 May 2017

(c) Author(s) 2017. CC-BY 3.0 License.

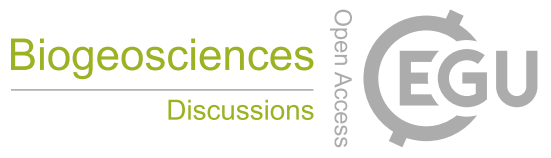

(c) (i)

472 This study examined the vulnerability of SOM of organic soils to decomposition by determining the specific basal 473 respiration rates under aerobic conditions in the laboratory. It was shown that the specific basal respiration increased in 474 magnitude and variability with increasing disturbance, and that it was at its highest and most variable at the boundary 475 between mineral and organic soils. At this boundary heavily degraded organic soil or peat soils mixed with mineral soil 476 prevailed, and therefore it was surprising that a decreasing trend of specific basal respiration with higher SOC was identified. 477 Furthermore, bog samples seemed to be more sensitive to anthropogenic disturbance than fen samples as indicated by a 478 stronger increase of specific respiration rates with increasing disturbance. Overall, the most important indicators for the 479 vulnerability of SOM identified in the present study were narrow C:N-ratios, higher pH-values, lower SOC content, and 480 higher concentrations of available phosphorus. There seems to be a positive feedback loop of disturbance and increased 481 mineralisation. However no explanation could be found for the very variable specific basal respiration of heavily disturbed 482 ("moorshy") fen peat and mineral soil-peat mixtures. For these types of soils, more sophisticated indicators of vulnerability 483 still need to be identified. Given the continued drainage and disturbance of peatlands and the considerable potential of $\mathrm{CO}_{2}$ 484 emissions from heavily disturbed organic soil presented here, future research needs to be concentrated on identifying 485 hotspots within these very heterogeneous soils for correctly targeting mitigation measures. Furthermore mixing peat with 486 mineral soils does not seem to be a promising option to mitigate emissions. 
Biogeosciences Discuss., doi:10.5194/bg-2017-127, 2017

Manuscript under review for journal Biogeosciences

Discussion started: 3 May 2017

(c) Author(s) 2017. CC-BY 3.0 License.

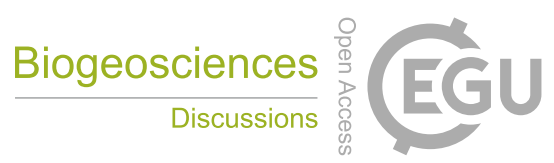

(c)

\section{Data availability}

488 Results of the incubation experiment and the soil properties of the samples are available as supplementary data. 
Biogeosciences Discuss., doi:10.5194/bg-2017-127, 2017

Manuscript under review for journal Biogeosciences

Discussion started: 3 May 2017

(c) Author(s) 2017. CC-BY 3.0 License.

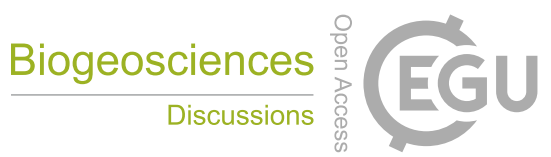

(c) (i)

\section{Appendix A}

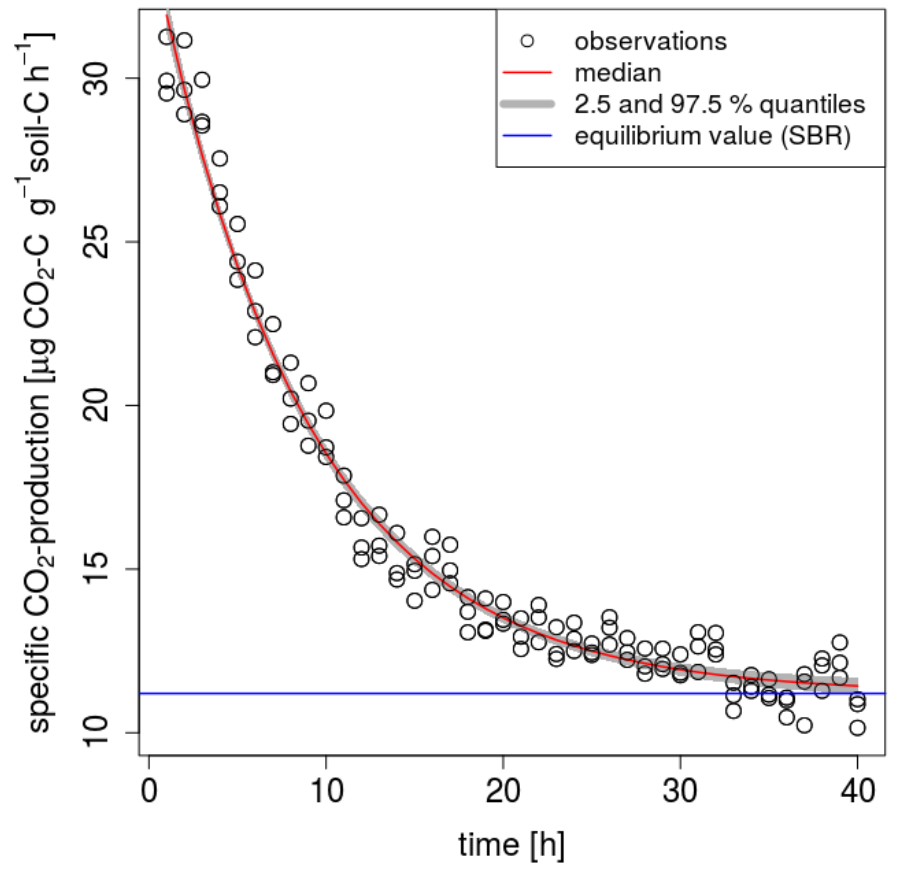

490

491 Figure A1: Specific $\mathrm{CO}_{2}$ production of three incubation replicates over time. Corresponding median including quantiles $(2.5$ and $97.5 \%)$ 492 and the equilibrium value of the SBR, as determined by the exponential model 
Biogeosciences Discuss., doi:10.5194/bg-2017-127, 2017

Manuscript under review for journal Biogeosciences

Discussion started: 3 May 2017

(c) Author(s) 2017. CC-BY 3.0 License.

493 Table A1: Classification of the degree of disturbance with corresponding soil horizons and description (Ad-Hoc-AG Boden, 2005; TGL

494 24300/04 in Succow and Joosten, 2001); abbreviations of soil horizons according to KA5 (Ad-Hoc-AG Boden, 2005)

\begin{tabular}{lll}
\hline $\begin{array}{l}\text { Degree of } \\
\text { disturbance }\end{array}$ & Soil horizon* Description
\end{tabular}

\begin{tabular}{|c|c|c|}
\hline No disturbance & $\mathrm{Hr}$ & $\begin{array}{l}\text { Permanently saturated and anaerobic ("reduced") conditions, not altered by secondary } \\
\text { pedogenetic processes, peat substrates can be identified. "Undisturbed horizons" may not } \\
\text { be confused with "undisturbed peatlands" as such horizons may appear at greater depth } \\
\text { of drained sites. }\end{array}$ \\
\hline
\end{tabular}

Slight disturbance $\quad \mathrm{Hw}$

Moderate

disturbance

$\mathrm{Hv}$

Strong disturbance $\mathrm{Ht}, \mathrm{Ha}$

Heavy disturbance $\quad \mathrm{Hm}, \mathrm{Aa}, \mathrm{Hvp}$

Gyttja

fF

Other e.g.
Alternating saturated-unsaturated conditions and thus temporarily subjected to aerobic conditions, peat structure not yet altered by secondary pedogenetic processes.

Topsoil horizon of moderately drained sites, earthified, crumbly structure caused by aerobic decomposition, plant residuals not visible anymore, not dusty when dry.

Subsoil horizon of intensively drained sites, polyhedral aggregates caused by swelling and shrinkage, crumbly when dry (Ha) OR prismatic aggregates with vertical cracks (Ht) as transition horizon to underlying peat. Aggregate and shrinkage horizons have been combined in this class due to the very low number $(n=2)$ of shrinkage horizons in our sample set.

Topsoil horizon of intensively drained sites, "moorshy", dusty or small-grained structure when dry, intensive aerobic decomposition, plant residuals not visible anymore ("Mulm") OR horizons with a high content of mineral soil due to ploughing, mineralization, anthropogenic addition from external sources, or addition from natural sources (sedimentation in riverine fens or translocation by wind). All earthified ploughed horizons (Hvp) in our dataset had a low SOC content pointing to mixing with mineral soil and were thus classified as "heavily disturbed". Due to the strongly disturbed conditions of these topsoils, it was impossible to distinguish between the underlying different processes.

Organic or calcareous lacustrine sediments mainly in terrestrialization peatlands. Due to the lack of an English translation of the German term "Mudde", the term "gyttja" was used here for all these sediments, although it describes calcareous sediments only in the German classification system.

Organic marsh soils, buried horizons, horizons without peatland genesis, but with SOC > $8 \%$. 
Biogeosciences Discuss., doi:10.5194/bg-2017-127, 2017

Manuscript under review for journal Biogeosciences

Discussion started: 3 May 2017

(c) Author(s) 2017. CC-BY 3.0 License.

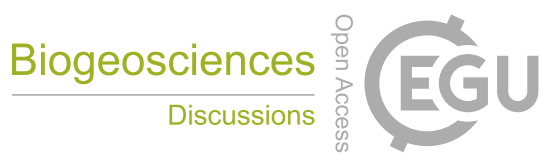

(c) (i)

\section{Competing interests}

497 The authors declare that they have no conflict of interest.

\section{Acknowledgements}

499 This study was carried out as part of the German Agricultural Soil Inventory, funded by the German Federal Ministry of 500 Food and Agriculture. We are grateful to the sampling teams coordinated by R. Prietz as well as to the laboratory team of A. 501 Heidkamp. We would like to thank A. Bauer for technical support during measurements and I. Backwinkel for $\mathrm{C}$ and $\mathrm{N}$ 502 analyses. We thank B. Grabellus for iron analysis at the University of Hamburg, L. Sauheitl for the opportunity to perform 503 isotope analysis at the University of Hanover and M. Gocke for P analysis at the University of Bonn. A special thanks to U. 504 Dettmann and A. Piayda for their help with DREAM modelling and general enduring support and encouragement. For 505 insightful discussions, ideas and comments, we also thank V. Alcántara, M. Bräuer, A. Jaconi, F. Kalks, C. Poeplau, C. 506 Riggers, F. Schneider, C. Vos and P. Wordell-Dietrich. 
Biogeosciences Discuss., doi:10.5194/bg-2017-127, 2017

Manuscript under review for journal Biogeosciences

Discussion started: 3 May 2017

(c) Author(s) 2017. CC-BY 3.0 License.

\section{References}

Ad-Hoc-Arbeitsgruppe Boden: Bodenkundliche Kartieranleitung KA5 (Manual of soil mapping), 5th ed., E. Schweizerbart'sche Verlagsbuchhandlung, Hanover, Germany, 2005. Ågren, G., Bosatta, E. and Balesdent, J.: Isotope discrimination during decomposition of organic matter: a theoretical analysis, Soil Sci. Soc. Am. J., 60(March), 1121-1126, doi:10.2136/sssaj1996.03615995006000040023x, 1996.

Amador, J. and Jones, R. D.: Nutrient limitations on microbial respiration in peat soils with different total phosphorus content, Soil Biol. Biochem., 25(6), 793-801, doi:10.1016/0038-0717(93)90125-U, 1993.

Anderson, J. P. E. and Domsch, K. H.: A physiological method for the quantitative measurement of microbial biomass in soils, Soil Biol. Biochem., 10, 215-221, doi:10.1016/0038-0717(78)90099-8, 1978.

Anderson, T.-H., Heinemeyer, O., Insam, H., Martens, R., Schlecht, S., Gehlen, P., Schuster, E. and Kowalczyk, T.: Methoden zur quantitativen Bestimmung und Charakterisierung der mikrobiellen Biomasse des Bodens, Wissenschaftliche Mitteilungen der Bundesforschungsanstalt für Landwirtschaft Braunschweig-Völkenrode, 160, 17-29 [online] Available from: http://agris.fao.org/agris-search/search.do?recordID=DE19960166084, 1995.

Anderson, T. H. and Domsch, K. H.: Determination of ecophysiological maintenance carbon requirements of soil microorganisms in a dormant state, Biol. Fertil. Soils, 1(2), 81-89, doi:10.1007/BF00255134, 1985.

Andersson, S. and Nilsson, S. I.: Influence of $\mathrm{pH}$ and temperature on microbial activity, substrate availability of soil-solution bacteria and leaching of dissolved organic carbon in a mor humus, Soil Biol. Biochem., 33(9), 1181-1191, doi:10.1016/S0038-0717(01)00022-0, 2001.

Ausec, L., Kraigher, B. and Mandic-Mulec, I.: Differences in the activity and bacterial community structure of drained grassland and forest peat soils, Soil Biol. Biochem., 41(9), 1874-1881, doi:10.1016/j.soilbio.2009.06.010, 2009.

Blodau, C.: Carbon cycling in peatlands - A review of processes and controls, Environ. Rev., 10(2), 111-134, doi:10.1139/a02-004, 2002.

Bohlin, E., Hämäläinen, M. and Sundén, T.: Botanical and chemical characterization of peat using multivariate methods, Soil Sci., 147(4), 252-263, 1989.

Brake, M., Höper, H. and Joergensen, R. G.: Land use-induced changes in activity and biomass of microorganisms in raised bog peats at different depths, Soil Biol. Biochem., 31(11), 1489-1497, doi:10.1016/S0038-0717(99)00053-X, 1999.

Bridgham, S. D. and Richardson, C. J.: Mechanisms controlling soil respiration $\left(\mathrm{CO}_{2}\right.$ and $\left.\mathrm{CH}_{4}\right)$ in southern peatlands, Soil Biol. Biochem., 24(11), 1089-1099, doi:10.1016/0038-0717(92)90058-6, 1992.

Brouns, K., Keuskamp, J. A., Potkamp, G., Verhoeven, J. T. A. and Hefting, M. M.: Peat origin and land use effects on microbial activity, respiration dynamics and exo-enzyme activities in drained peat soils in the Netherlands, Soil Biol. Biochem., 95, 144-155, doi:10.1016/j.soilbio.2015.11.018, 2016.

Chmieleski, J.: Zwischen Niedermoor und Boden: Pedogenetische Untersuchungen und Klassifikation von mitteleuropäischen Mudden, Berlin, Germany, 2006. 
Biogeosciences Discuss., doi:10.5194/bg-2017-127, 2017

Manuscript under review for journal Biogeosciences

Discussion started: 3 May 2017

(c) Author(s) 2017. CC-BY 3.0 License.

Clymo, R. S., Turunen, J. and Tolonen, K.: Carbon accumulation in peatland, Oikos, 81(2), 368-388, doi:10.2307/3547057, 1998.

Don, A., Rödenbeck, C. and Gleixner, G.: Unexpected control of soil carbon turnover by soil carbon concentration, Environ. Chem. Lett., 11(4), 407-413, doi:10.1007/s10311-013-0433-3, 2013.

Fisk, M. C., Ruether, K. F. and Yavitt, J. B.: Microbial activity and functional composition among northern peatland ecosystems, Soil Biol. Biochem., 35(4), 591-602, doi:10.1016/S0038-0717(03)00053-1, 2003.

Freeman, C., Liska, G., Ostle, N. J., Lock, M. A., Reynolds, B. and Hudson, J.: Microbial activity and enzymic decomposition processes following peatland water table drawdown, Plant Soil, 180(1), 121-127, doi:10.1007/BF00015418, 1996.

Freeman, C., Ostle, N. and Kang, H.: An enzymic "latch" on a global carbon store., Nature, 409(6817), 149, doi:10.1038/35051650, 2001.

Fuentes, J. P., Bezdicek, D. F., Flury, M., Albrecht, S. and Smith, J. L.: Microbial activity affected by lime in a long-term no-till soil, Soil Tillage Res., 88(1-2), 123-131, doi:10.1016/j.still.2005.05.001, 2006.

Gelman, A. and Rubin, D. B.: Inference from iterative simulation using multiple sequences, Stat. Sci., 7(4), 457-511, 1992.

Glatzel, S., Basiliko, N., Moore, T. and Unit, L. E.: Carbon dioxide and methane production potentials of peats from natural, harvested and restored sites, Eastern Quebec, Canada, Wetlands, 24(2), 261-267, doi:10.1672/02775212(2004)024[0261:CDAMPP]2.0.CO;2, 2004.

Gorham, E.: Northern peatlands: Role in the carbon cycle and probably responses to climate warming, Ecol. Appl., 1(2), 182-195, doi:10.2307/1941811, 1991.

Göttlich, K.: Moor- und Torfkunde, E. Schweizerbart'sche Verlagsbuchhandlung (Nägele u. Obermiller), Stuttgart, Germany, 1990.

Guillaume, J. and Andrews, F.: dream: DiffeRential Evolution Adaptive Metropolis. R package version 0.4-2, available at http://CRAN.R-project.org/package=dream, 2012.

Harrell, F.: Hmisc: Harrell Miscellaneous. $\mathrm{R}$ package version 3.17-4, available at http://CRAN.Rproject.org/package=Hmisc, 2016.

Harris, D., Horwáth, W. R. and van Kessel, C.: Acid fumigation of soils to remove carbonates prior to total organic carbon or carbon-13 isotopic analysis, Soil Sci. Soc. Am. J., 65(6), 1853, doi:10.2136/sssaj2001.1853, 2001.

Hassink, J.: The capacity of soils to preserve organic C and N by their association with clay and silt particles, Plant Soil, 191(1), 77-87, doi:10.1023/A:1004213929699, 1997.

Hedges, J. I. and Stern, J. H.: Carbon and nitrogen determinations of carbonate-containing solids, Limnol. Oceanogr., 29(3), 657-663, doi:10.4319/lo.1984.29.3.0657, 1984.

Heinemeyer, O., Insam, H., Kaiser, E. A. and Walenzik, G.: Soil microbial biomass and respiration measurements: An automated technique based on infra-red gas analysis, Plant Soil, 116, 191-195, 1989.

Holden, J., Chapman, P. J. and Labadz, J. C.: Artificial drainage of peatlands: hydrological and hydrochemical process and 
Biogeosciences Discuss., doi:10.5194/bg-2017-127, 2017

Manuscript under review for journal Biogeosciences

Discussion started: 3 May 2017

(c) Author(s) 2017. CC-BY 3.0 License.

wetland restoration, Prog. Phys. Geogr., 28(1), 95-123, doi:10.1191/0309133304pp403ra, 2004.

Hothorn, T., Westfall, F. and Peter, B.: Simultaneous inference in general parametric models, Biometrical J., 50(3), 346-363, doi:10.1002/bimj.200810425, 2008.

Ilnicki, P. and Zeitz, J.: Irreversible loss of organic soil functions after reclamation, in Organic Soils and Peat Materials for Sustainable Agriculture, edited by L. E. Parent and P. Ilnicki, CRC Press LLC, Boca Raton, USA, 2003.

Joosten, H. and Clarke, D.: Wise use of mires and peatlands, International Mire Conservation Group and International Peat Society, Saarijärvi, Finland, 2002.

Kaiser, E. A., Mueller, T., Joergensen, R. G., Insam, H. and Heinemeyer, O.: Evaluation of methods to estimate the soil microbial biomass and the relationship with soil texture and organic matter, Soil Biol. Biochem., 24(7), 675-683, doi:10.1016/0038-0717(92)90046-Z, 1992.

Krüger, J. P., Leifeld, J. and Alewell, C.: Degradation changes stable carbon isotope depth profiles in palsa peatlands, Biogeosciences, 11(12), 3369-3380, doi:10.5194/bg-11-3369-2014, 2014.

Krüger, J. P., Leifeld, J., Glatzel, S., Szidat, S. and Alewell, C.: Biogeochemical indicators of peatland degradation - A case study of a temperate bog in northern Germany, Biogeosciences, 12(10), 2861-2871, doi:10.5194/bg-12-2861-2015, 2015.

Kuhry, P. and Vitt, D. H.: Fossil carbon/nitrogen ratios as a measure of peat decomposition, Ecology, 77(1), 271-275, 1996.

Laiho, R.: Decomposition in peatlands: reconciling seemingly contrasting results on the impacts of lowered water levels, Soil Biol. Biochem., 38(8), 2011-2024, doi:10.1016/j.soilbio.2006.02.017, 2006.

Laiho, R., Sallantaus, T. and Laine, J.: The effect of forestry drainage on vertical distributions of major plant nutrients in peat soils, Plant Soil, 207(2), 169-181, doi:10.1023/A:1026470212735, 1998.

Lehmann, J. and Kleber, M.: Perspective The contentious nature of soil organic matter, Nature, 528, 60-68, doi:10.1038/nature16069, 2015.

Leiber-Sauheitl, K., Fuß, R., Voigt, C. and Freibauer, A.: High $\mathrm{CO}_{2}$ fluxes from grassland on histic gleysol along soil carbon and drainage gradients, Biogeosciences, 11(3), 749-761, doi:10.5194/bg-11-749-2014, 2014.

Maljanen, M., Sigurdsson, B. D., Guömundsson, J., Öskarsson, H., Huttunen, J. T. and Martikainen, P. J.: Greenhouse gas balances of managed peatlands in the Nordic countries present knowledge and gaps, Biogeosciences, 7(9), 2711-2738, doi:10.5194/bg-7-2711-2010, 2010.

Montanarella, L., Jones, R. J. A. and Hiederer, R.: The distribution of peatland in Europe., Mires Peat, 1(1), 1-10, doi:10.1017/CBO9781107415324.004, 2006.

Murphy, J. and Riley, J. P.: A modified single solution method for the determination of phosphate in natural waters, Anal. Chim. Acta, 27, 31-36, doi:doi:10.1016/S0003-2670(00)88444-5, 1962.

Nadelhoffer, K., Shaver, G., Fry, B., Giblin, A., Johnson, L. and McKane, R.: ${ }^{15} \mathrm{~N}$ natural abundances and N use by tundra plants, Oecologia, 107(3), 386-394, doi:10.1007/BF00328456, 1996.

Okruszko, H.: Agricutural use of peatlands, in Global Peat Resources, edited by E. Lappalainen, pp. 303-309, International Peat Society, Jyskä, Finland, 1996. 
Biogeosciences Discuss., doi:10.5194/bg-2017-127, 2017

Manuscript under review for journal Biogeosciences

Discussion started: 3 May 2017

(c) Author(s) 2017. CC-BY 3.0 License.

Pinheiro, J., Bates, D., DebRoy, S. and Sarkar, D.: nlme: Linear and nonlinear mixed effects models, R package version 3.1120, availabe at: http://CRAN.R-project.org/package=nlme, 2015.

von Post, L.: Das genetische System der organogenen Bildungen Schwedens, Com. Int. Pédologie, IVème Comm. pour l'Europe, 22, 287-304, 1924.

R Core Team: A language and environment for statistical computing. R-3.1.3 R Foundation for Statistical Computing, Vienna, Austria, available at: http://www.R-project.org/, 2015.

Reiche, M., Gleixner, G. and Küsel, K.: Effect of peat quality on microbial greenhouse gas formation in an acidic fen, Biogeosciences, 7(5), 187-198, doi:10.5194/bgd-6-8775-2009, 2010.

Ross, S. M. and Malcolm, D. C.: Modelling nutrient mobilisation in intensively mixed peaty heathland soil, Plant Soil, 107(1), 113-121, doi:10.1007/BF02371552, 1988.

Rovdan, E., Witkowska-Walczak, B., Walczak, R. and Sawinski, C.: Changes in the hydrophysical properties of peat soils under anthropogenic evolution, Int. Agrophysics, 219-226, 2002.

Saidy, A. R., Smernik, R. J., Baldock, J. A., Kaiser, K., Sanderman, J. and Macdonald, L. M.: Effects of clay mineralogy and hydrous iron oxides on labile organic carbon stabilisation, Geoderma, 173-174, 104-110, doi:10.1016/j.geoderma.2011.12.030, 2012.

Schlichting, A., Leinweber, P., Meissner, R. and Altermann, M.: Sequentially extracted phosphorus fractions in peat-derived soils, J. Plant Nutr. Soil Sci., 165(3), 290-298, doi:10.1002/1522-2624(200206)165:3<290::AID-JPLN290>3.0.CO;2-A, 2002.

Schüller, H.: Die CAL-Methode, eine neue Methode zur Bestimmung des pflanzenverfügbaren Phosphates in Boden, J. Plant Nutr. Soil Sci., 123(1), 48-63, doi:doi:10.1002/jpln.19691230106, 1969.

Schulz, S. and Waldeck, A.: Kohlenstoffreiche Böden auf Basis hochauflösender Bodendaten in Niedersachsen, State Authority for Mining, Energy and Geology, Hanover, Germany, 2015.

Schwertmann, U.: Differenzierung der Eisenoxide des Bodens durch Extraktion mit Ammoniumoxalat-Lösung, Z. Pflanzenernähr. Düng. Bodenk, 105, 194-202, doi:10.1002/jpln.3591050303, 1964.

Six, J., Conant, R. T., Paul, E. A. and Paustian, K.: Stabilization mechanisms of soil organic matter: Implications for Csaturation of soils, Plant Soil, 241(2), 155-176, doi:doi:10.1023/A:1016125726789, 2016.

Succow, M. and Joosten, H.: Landschaftsökologische Moorkunde, E. Schweizerbart'sche Verlagsbuchhandlung (Nägele u. Obermiller), Stuttgart, Germany, 2001.

Sundström, E., Magnusson, T. and Hånell, B.: Nutrient conditions in drained peatlands along a north-south climatic gradient in Sweden, For. Ecol. Manage., 126(2), 149-161, doi:10.1016/S0378-1127(99)00098-5, 2000.

Tiemeyer, B., Albiac Borraz, E., Augustin, J., Bechtold, M., Beetz, S., Beyer, C., Drösler, M., Ebli, M., Eickenscheidt, T., Fiedler, S., Förster, C., Freibauer, A., Giebels, M., Glatzel, S., Heinichen, J., Hoffmann, M., Höper, H., Jurasinski, G., Leiber-Sauheitl, K., Peichl-Brak, M., Roßkopf, N., Sommer, M. and Zeitz, J.: High emissions of greenhouse gases from grasslands on peat and other organic soils, Glob. Chang. Biol., 22, 4134-4149, doi:10.1111/gcb.13303, 2016. 
Biogeosciences Discuss., doi:10.5194/bg-2017-127, 2017

Manuscript under review for journal Biogeosciences

Discussion started: 3 May 2017

(c) Author(s) 2017. CC-BY 3.0 License.

Toberman, H., Tipping, E., Boyle, J. F., Helliwell, R. C., Lilly, A. and Henrys, P. A.: Dependence of ombrotrophic peat nitrogen on phosphorus and climate, Biogeochemistry, 125(1), 11-20, doi:10.1007/s10533-015-0117-0, 2015.

Tubiello, F. N., Biancalani, R., Salvatore, M., Rossi, S. and Conchedda, G.: A worldwide assessment of greenhouse gas emissions from drained organic soils, Sustainability, 8(4), 1-13, doi:10.3390/su8040371, 2016.

Urbanová, Z. and Bárta, J.: Microbial community composition and in silico predicted metabolic potential reflect biogeochemical gradients between distinct peatland types, FEMS Microbiol. Ecol., 90(3), 633-646, doi:10.1111/15746941.12422, 2014.

Urbanová, Z. and Bárta, J.: Effects of long-term drainage on microbial community composition vary between peatland types, Soil Biol. Biochem. J., 92, 16-26, doi:10.1016/j.soilbio.2015.09.017, 2015.

Verhoeven, J. T. A. and Liefveld, W. M.: The ecological significance of organochemical compounds in Sphagnum, Acta Bot. Neerl., 46(2), 117-130, doi:10.1111/plb.1997.46.2.117, 1997.

Verhoeven, J. T. A., Maltby, E. and Schmitz, M. B.: Nitrogen and phosphorus mineralization in fens and bogs, J. Ecol., 78, 713-726, doi:10.2307/2260894, 1990.

Vos, C., Don, A., Prietz, R., Heidkamp, A. and Freibauer, A.: Field-based soil-texture estimates could replace laboratory analysis, Geoderma, 267, 215-219, doi:10.1016/j.geoderma.2015.12.022, 2016.

Vrugt, J. A., ter Braak, C. J. F., Clark, M. P., Hyman, J. M. and Robinson, B. A.: Treatment of input uncertainty in hydrologic modeling: Doing hydrology backward with Markov chain Monte Carlo simulation, Water Resour. Res., 44, 1-52, doi:10.1029/2007WR006720, 2008.

Vrugt, J. A., ter Braak, C. J. F., Diks, C. G. H., Robinson, B. A., Hyman, J. M. and Higdon, D.: Accelerating Markov Chain Monte Carlo simulation by differential evolution with self-adaptive randomized subspace sampling, Int. J. Nonlinear Sci. Numer. Simul., 10(3), 273-290, doi:10.1515/IJNSNS.2009.10.3.273, 2009a.

Vrugt, J. A., ter Braak, C. J. F., Gupta, H. V. and Robinson, B. A.: Equifinality of formal (DREAM) and informal (GLUE) Bayesian approaches in hydrologic modeling?, Stoch. Environ. Res. Risk Assess., 23(7), 1011-1026, doi:10.1007/s00477008-0274-y, 2009b.

Wagai, R. and Mayer, L. M.: Sorptive stabilization of organic matter in soils by hydrous iron oxides, Geochim. Cosmochim. Acta, 71(1), 25-35, doi:10.1016/j.gca.2006.08.047, 2007.

Wang, W. J., Dalal, R. C., Moody, P. W. and Smith, C. J.: Relationship of soil respiration and microboial biomass, substrate availability and clay content., Soil Biol Biochem, 35, 273-284, doi:doi:10.1016/S0038-0717(02)00274-2, 2003.

Wells, E. D. and Williams, B. L.: Effects of drainage, tilling and PK-fertilization on bulk density, total N, P, K, Ca and Fe and net N-mineralization in two peatland forestry sites in Newfoundland, Canada, For. Ecol. Manage., 84(1-3), 97-108, doi:10.1016/0378-1127(96)03741-3, 1996.

Williams, B. L. and Wheatley, R. E.: Nitrogen mineralization and water-table height in oligotrophic deep peat, Biol. Fertil. Soils, 6(2), 141-147, doi:10.1007/BF00257664, 1988. Zak, D., Wagner, C., Payer, B., Augustin, J. and Gelbrecht, J.: Phosphorus mobilization in rewetted fens: The effect of 
Biogeosciences Discuss., doi:10.5194/bg-2017-127, 2017

Manuscript under review for journal Biogeosciences

Discussion started: 3 May 2017

(c) Author(s) 2017. CC-BY 3.0 License.

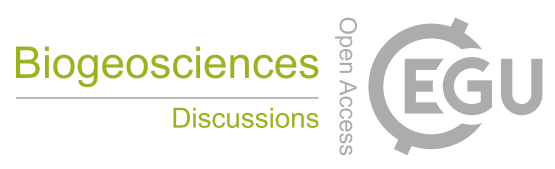

(c) (i)

676 altered peat properties and implications for their restoration, Ecol. Appl., 20(5), 1336-1349, doi:10.1890/08-2053.1, 2010.

677 Zuur, A. F., Ieno, E. N., Walker, N. J., Saveliev, A. A. and Smith, G. M.: Mixed Effects Models and Extensions in Ecology

678 with R, edited by M. Gail, K. Krickeberg, J. M. Samet, A. Tsiatis, and W. Wong, Springer Science and Business Media,

679 New York, USA, 2009.

680 